\title{
Evaluation of brick kiln operation impact on soil microbial biomass and enzyme activity
}

\author{
Nasrin Chowdhury ${ }^{1 *}$, Md. Mamunur Rasid ${ }^{2}$ \\ University of Chittagong, Faculty of Biological Sciences, Department of Soil Science, Chittagong University Road, 4331, Chattogram, Bangladesh
}

* Dr. N. Chowdhury, email: nasrin@cu.ac.bd

Received: 26.08 .2020

Accepted: 07.01.2021

Associated editor: J. Wyszkowska

\section{Keywords}

Brick kiln cluster

Agricultural soil

$\mathrm{Cd}$ and $\mathrm{Pb}$ contamination

Potential ecological risk index

Microbial metabolic quotient

$\mathrm{ED}_{50}$

\begin{abstract}
Heavy metal emission from brick kiln operation in developing countries is one of the major sources of environmental pollution. The present study evaluated the intensity of $\mathrm{Cd}$ and $\mathrm{Pb}$ pollution and the impact on soil microbial activity in agricultural soils in the vicinity of the brick kiln cluster of Hathazari, Chattogram, Bangladesh. It is a major concern as anthropogenic stress on soil microorganisms is directly related to crop productivity. Soil samples were collected from 21 sites covering 7 locations including the reference sites for the assessment of the toxic impact on soil biota. Soil samples were analyzed using standard procedures. In some of the sampling sites, $\mathrm{Cd}$ and $\mathrm{Pb}$ concentrations were significantly higher than the reference sites. Metal concentration indicates that the anthropogenic input in the soils was in the range of 0.27 to $1.07 \mathrm{mg} \cdot \mathrm{kg}^{-1}$ of Cd and 19.07 to $52.07 \mathrm{mg} \cdot \mathrm{kg}^{-1} \mathrm{of} \mathrm{Pb}$. However, the concentrations of $\mathrm{Pb}$ were not in toxic concentration when compared to the standard level by Chinese environmental quality standards for soil. The highest contamination degree (PER) of the soils was 200.87 and the lowest was 115.83. The contamination factor demonstrated that the soils were in the moderate to considerable level of contamination. The results showed that the number of soil microbial population, microbial activity, microbial biomass carbon, dehydrogenase, urease, acid phosphatase and arylsulfatase activities in the reference soil were all higher than in the agricultural soil in the vicinity of brick kiln cluster. Exponential curves showed a significant positive correlation between heavy metal and microbial metabolic quotient $\left(q \mathrm{CO}_{2}\right)$ indicating metal stress and high concentration of heavy metals decreased microbial biomass and enzyme activity. Soil pH and Cd content were identified as the key influential factors controlling soil biological functions. A significantly high correlation was observed for $\mathrm{Cd}$ and $\mathrm{Pb}(\mathrm{r}=0.89, \mathrm{p}<0.001)$, it suggests the same source of contamination input. Contamination of $\mathrm{Cd}$ and $\mathrm{Pb}$ is attributed to heavy input of aerial deposits of metal-enriched fumes from brick kiln operation. A significant negative impact of $\mathrm{Cd}$ and $\mathrm{Pb}$ on soil microbial activities and enzyme activities was also profound from correlation studies and PCA analysis. However, regular application of fertilizer in agricultural soils may have supported adaptation to long-term $\mathrm{Cd}$ stress mainly through the maintenance of microbial activity. The study is important in eco-toxicological and biomonitoring aspects as the data on heavy metal toxicity to the soil environment can act as guidelines for the continuation of brick kiln operation and the sustainable utilization of natural resources.
\end{abstract}

\section{Introduction}

Environmental pollution is a global problem. However, the source and increase in pollution in developing countries are different and drastic compared to the developed countries. The environmental impact of brick production has become an earnest concern. Air pollution and land degradation from brick kiln's emission are regular in developing countries, adversely affecting the environment of its surroundings (Biswas et al., 2018). Rapid urbanization created a booming in the construction industry. Brick is the principal building material for some countries where stone aggregate is not available. The brick sector in a developing country is specified by firing technologies, environmental pollution, reliance on man- ual labor and use of soil as essential raw material. Brick kilns are very energy-intensive and highly polluting, they usually burn lowquality coal with high sulfur (about 5 percent), clinker, wood dust, furnace oil, rubber tires, plastics and wood (Tusher et al., 2018). The incomplete combustion process of brick kiln furnaces releases solid particles and greenhouse gases. The pollutants are suspended particulate matter, carbon monoxide, carbon dioxide and heavy metals in fumes (Skinder et al., 2014). The large brick kiln clusters, located in the vicinity of large brick demand centers are a major cause of concern, the pollution impact from the emission from single isolated brick kilns located in rural areas is not significant.

Long term brick kiln operation can cover the surface area of the local vegetation and soil with brick kiln dust which may cause 
significant change to the physicochemical properties as well as the nutrient status of nearby soil with ultimate rigorous impact on soil ecology (Islam et al., 2015; Sarkar et al., 2016). The burning of enormous carbon $(\mathrm{C})$ and nitrogen $(\mathrm{N})$ in brick kiln degrades the soils and led to a threat for atmospheric pollution and climate change (Khan et al., 2007). Which further results in crop yield reduction, marginal vegetation growth as well as soil degradation and reduction of microbial activity and nutrient cycling (Sharma, 2000). Mobility and bioavailability of heavy metals are considerably increased in comparison with the original waste by the incineration process. Heavy metals are generated from the brick furnace as aerial pollutants deposited shortly to the surroundings and distributed in soils and water sources. An enormous amount of heavy metal can be deposited in the biosphere as the loading rate is approximately 20 times higher than the removal rate (Ravankhah et al., 2017). Heavy metals as a soil pollutant can be an issue of concern for their persistence, toxicity and bioaccumulation (Li et al., 2015). The concentration of $\mathrm{Cd}$ and $\mathrm{Pb}$ in agricultural soil of brick kiln area was outlined to be more than the regulatory standards imposed by the US Environmental Protection Agency (Ismail et al., 2012).

Bangladesh is the fourth-largest producer of clay fired bricks in the world after China, India and Pakistan. There are more than 7,000 brick kilns, producing about 27 billion bricks annually (Eil et al., 2020). Brick kiln emission is the largest source of greenhouse gas emissions in Bangladesh estimated to be 15.67 million tons of $\mathrm{CO}_{2}$ annually (Imran et al., 2014). Traditional kilns in Bangladesh have particulate emissions above $1,000 \mathrm{mg}^{2}$ per $\mathrm{m}^{3}$ and coal consumption of 20-22 tons per 100,000 bricks produced (Haque et al., 2018). A plethora of information is available for heavy metal pollution in agricultural soils of Bangladesh (e.g. Chowdhury and Rasid, 2016; Ahmed et al., 2018; Proshad et al., 2019; Mallick et al.,
2019; Hasan et al., 2020; Alam et al., 2020). Some studies focused on heavy metal contamination of agricultural soils by heavy traffic (e.g. Aktaruzzaman et al., 2013; Zakir et al., 2014; Tasrina et al., 2015). Elevated concentrations of heavy metals were detected in some of the studies, which have contributed to the declined soil health and crop yields. However, no detailed study on soil microbial biomass and enzyme activity in agricultural soil concerning heavy metals impact from brick kiln clusters have been conducted yet. Several huge clusters of the brick kiln are present in Hathazari, Chattogram which can be an important source of $\mathrm{Cd}$ and $\mathrm{Pb}$ toxicity with the potential to harm the ecology of the surrounding agricultural soil (Ravankhah et al., 2017). Soil degradation and environmental pollution are not inevitable but can be controlled if major abuses are avoided and improved methods of environmental management are developed. With this background, the stress effect of $\mathrm{Cd}$ and $\mathrm{Pb}$ on soil microbial and enzyme activities was evaluated.

\section{Materials and methods}

\subsection{Study area and soil sampling}

A cluster of the brick kiln was selected which were surrounded by agricultural fields in the Charia area, Hathazari, Chittagong district, Bangladesh. The sampling from the study area was carried out during the dry seasons as the brick kilns are the major source of air pollution during the manufacturing season of October to March, depending on the monsoonal rains. Emitterinfluenced sampling locations were set based on crops growing and distance from the brick kiln cluster (A-F) (Table 1). At these locations, three different crop fields were selected and three soil

\section{Table 1}

Physicochemical properties (mean \pm SD) of different agricultural soils adjacent to the brick kiln cluster, Hathazari, Chattogram

Each mean is the average of the values obtained for three samples of each soil. Values in the same column followed by the same letter(s) are not significantly different at $\mathrm{p}<0.05$ according to ANOVA.

$[\mathrm{OM}=$ Organic matter, Total $\mathrm{N}=$ Total nitrogen, Av P = Available phosphorus, Total $\mathrm{Pb}=$ Total lead concentration, Total $\mathrm{Cd}=$ Total cadmium concentration, $\mathrm{SD}=$ Standard deviation]

\begin{tabular}{|c|c|c|c|c|c|c|c|c|}
\hline Location & Sites & $\mathrm{pH}$ & $\begin{array}{l}\text { Clay } \\
\%\end{array}$ & $\begin{array}{l}\mathrm{OM} \\
\%\end{array}$ & $\begin{array}{l}\text { Total N } \\
\%\end{array}$ & $\begin{array}{l}\mathrm{AvP} \\
\mathrm{mg} \cdot \mathrm{kg}^{-1}\end{array}$ & $\begin{array}{l}\text { Total } \mathrm{Pb} \\
\mathrm{mg} \cdot \mathrm{kg}^{-1}\end{array}$ & $\begin{array}{l}\text { Total Cd } \\
\mathrm{mg} \cdot \mathrm{kg}^{-1}\end{array}$ \\
\hline \multirow{3}{*}{ A } & S1 & $4.87 \pm 0.08^{\mathrm{f}}$ & $22.82^{\mathrm{ab}}$ & $0.67 \pm 0.02^{\mathrm{ab}}$ & $0.16 \pm 0.00^{\mathrm{g}}$ & $7.14 \pm 0.10^{g}$ & $45.39 \pm 0.05^{\circ}$ & $1.00 \pm 0.01^{\mathrm{m}}$ \\
\hline & S2 & $5.39 \pm 0.03^{\mathrm{i}}$ & $27.71^{\text {cde }}$ & $1.19 \pm 0.05^{\mathrm{i}}$ & $0.19 \pm 0.01^{i j}$ & $8.92 \pm 0.79^{i}$ & $38.83 \pm 0.02^{\mathrm{n}}$ & $0.63 \pm 0.06^{\mathrm{h}}$ \\
\hline & S3 & $5.26 \pm 0.03^{h}$ & $23.92^{\mathrm{abc}}$ & $0.88 \pm 0.03^{\mathrm{d}}$ & $0.12 \pm 0.01^{\mathrm{de}}$ & $6.87 \pm 0.11^{\mathrm{fg}}$ & $27.33 \pm 0.03^{\text {hi }}$ & $0.98 \pm 0.01^{\mathrm{m}}$ \\
\hline \multirow{3}{*}{ B } & S4 & $4.15 \pm 0.05^{\mathrm{a}}$ & $24.25^{\mathrm{abc}}$ & $1.11 \pm 0.05^{\mathrm{gh}}$ & $0.15 \pm 0.00^{\mathrm{f}}$ & $3.64 \pm 0.34^{b}$ & $28.38 \pm 0.65^{\mathrm{ij}}$ & $0.66 \pm 0.02^{\mathrm{h}}$ \\
\hline & S5 & $5.62 \pm 0.00^{\mathrm{k}}$ & $30.67^{\operatorname{defg}}$ & $1.44 \pm 0.00^{\mathrm{k}}$ & $0.19 \pm 0.00^{\mathrm{i}}$ & $12.18 \pm 0.21^{\mathrm{k}}$ & $25.34 \pm 0.33^{f}$ & $0.46 \pm 0.01^{\mathrm{f}}$ \\
\hline & S6 & $5.07 \pm 0.02^{g}$ & $22.84^{\mathrm{ab}}$ & $0.95 \pm 0.05^{\mathrm{de}}$ & $0.11 \pm 0.01^{\mathrm{ab}}$ & $9.48 \pm 0.06^{j}$ & $52.07 \pm 0.03^{p}$ & $1.07 \pm 0.01^{\mathrm{n}}$ \\
\hline \multirow{3}{*}{ C } & S7 & $4.44 \pm 0.11^{\mathrm{b}}$ & $34.13^{\mathrm{g}}$ & $0.76 \pm 0.00^{c}$ & $0.13 \pm 0.00^{\mathrm{e}}$ & $2.79 \pm 0.38^{\mathrm{a}}$ & $31.40 \pm 0.07^{\mathrm{k}}$ & $0.71 \pm 0.00^{\mathrm{i}}$ \\
\hline & S8 & $5.76 \pm 0.08^{1}$ & $27.33^{\mathrm{bcd}}$ & $1.22 \pm 0.06^{\mathrm{i}}$ & $0.19 \pm 0.00^{\mathrm{i}}$ & $6.45 \pm 0.02^{\mathrm{f}}$ & $26.17 \pm 1.27^{\mathrm{fg}}$ & $0.55 \pm 0.00^{\mathrm{g}}$ \\
\hline & s9 & $6.30 \pm 0.02^{\circ}$ & $32.83^{\mathrm{g}}$ & $1.67 \pm 0.07^{1}$ & $0.20 \pm 0.00^{j}$ & $13.44 \pm 0.07^{1}$ & $20.75 \pm 0.14^{\mathrm{d}}$ & $0.31 \pm 0.05^{\mathrm{cd}}$ \\
\hline \multirow{3}{*}{$\mathrm{D}$} & S10 & $4.56 \pm 0.03^{\text {cd }}$ & $32.35^{\mathrm{fg}}$ & $0.91 \pm 0.07^{\mathrm{d}}$ & $0.11 \pm 0.01^{\mathrm{bc}}$ & $2.65 \pm 0.38^{\mathrm{a}}$ & $33.52 \pm 0.10^{1}$ & $0.88 \pm 0.01^{\mathrm{k}}$ \\
\hline & S11 & $5.07 \pm 0.09^{g}$ & $22.82^{\mathrm{ab}}$ & $1.06 \pm 0.00^{\mathrm{fg}}$ & $0.16 \pm 0.01^{\mathrm{gh}}$ & $4.38 \pm 0.16^{\mathrm{cd}}$ & $22.05 \pm 0.02^{\mathrm{e}}$ & $0.31 \pm 0.01^{\mathrm{d}}$ \\
\hline & S12 & $5.37 \pm 0.02^{\mathrm{i}}$ & $27.74^{\text {cdef }}$ & $1.36 \pm 0.08^{j}$ & $0.23 \pm 0.01^{1}$ & $5.43 \pm 0.08^{\mathrm{e}}$ & $20.73 \pm 0.04^{\mathrm{d}}$ & $0.28 \pm 0.01^{\mathrm{cd}}$ \\
\hline \multirow{3}{*}{ E } & S13 & $4.77 \pm 0.06^{\mathrm{e}}$ & $22.95^{\mathrm{ab}}$ & $1.01 \pm 0.05^{\mathrm{ef}}$ & $0.15 \pm 0.00^{\mathrm{f}}$ & $5.70 \pm 0.10^{\mathrm{e}}$ & $29.16 \pm 0.03^{j}$ & $0.70 \pm 0.01^{\mathrm{i}}$ \\
\hline & S14 & $4.55 \pm 0.04^{\mathrm{cd}}$ & $22.63^{a}$ & $0.65 \pm 0.05^{\mathrm{ab}}$ & $0.11 \pm 0.01^{\mathrm{bc}}$ & $3.83 \pm 0.26^{b}$ & $37.54 \pm 0.38^{\mathrm{m}}$ & $0.92 \pm 0.01^{1}$ \\
\hline & S15 & $5.50 \pm 0.01^{j}$ & $27.02^{\mathrm{abcd}}$ & $1.22 \pm 0.00^{\mathrm{i}}$ & $0.17 \pm 0.00^{\mathrm{h}}$ & $3.89 \pm 0.28^{\mathrm{bc}}$ & $19.07 \pm 0.02^{\mathrm{c}}$ & $0.27 \pm 0.02^{c}$ \\
\hline \multirow{3}{*}{$\mathrm{F}$} & S16 & $4.58 \pm 0.10^{\mathrm{d}}$ & $22.63^{\mathrm{a}}$ & $0.60 \pm 0.00^{\mathrm{a}}$ & $0.11 \pm 0.00^{\mathrm{abc}}$ & $4.56 \pm 0.13^{d}$ & $32.55 \pm 0.53^{1}$ & $0.82 \pm 0.01^{j}$ \\
\hline & S17 & $5.89 \pm 0.04^{\mathrm{m}}$ & $22.63^{\mathrm{a}}$ & $0.76 \pm 0.00^{c}$ & $0.12 \pm 0.01^{\mathrm{cd}}$ & $8.05 \pm 0.51^{\mathrm{h}}$ & $22.07 \pm 0.03^{e}$ & $0.37 \pm 0.02^{\mathrm{e}}$ \\
\hline & S18 & $4.48 \pm 0.02^{\mathrm{bc}}$ & $22.51^{\mathrm{a}}$ & $0.68 \pm 0.00^{\mathrm{b}}$ & $0.10 \pm 0.01^{\mathrm{a}}$ & $7.92 \pm 0.36^{\mathrm{h}}$ & $27.19 \pm 1.42^{\mathrm{gh}}$ & $0.56 \pm 0.03^{g}$ \\
\hline \multirow{3}{*}{$\mathrm{R}$} & S19 & $5.56 \pm 0.02^{\mathrm{jk}}$ & $27.90^{\text {cdef }}$ & $1.16 \pm 0.00^{\mathrm{hi}}$ & $0.21 \pm 0.00^{\mathrm{k}}$ & $14.35 \pm 0.49^{\mathrm{m}}$ & $9.22 \pm 0.06^{b}$ & $0.17 \pm 0.01^{\mathrm{b}}$ \\
\hline & S20 & $6.07 \pm 0.02^{\mathrm{n}}$ & $26.20^{\mathrm{abcd}}$ & $1.22 \pm 0.06^{\mathrm{i}}$ & $0.22 \pm 0.00^{1}$ & $15.12 \pm 0.04^{\mathrm{n}}$ & $9.01 \pm 0.77^{\mathrm{b}}$ & $0.13 \pm 0.00^{\mathrm{a}}$ \\
\hline & S21 & $5.88 \pm 0.01^{\mathrm{m}}$ & $32.03^{\text {efg }}$ & $1.22 \pm 0.06^{\mathrm{i}}$ & $0.22 \pm 0.01^{1}$ & $14.48 \pm 0.07^{\mathrm{m}}$ & $5.96 \pm 2.07^{a}$ & $0.14 \pm 0.00^{\mathrm{ab}}$ \\
\hline
\end{tabular}


subsamples were collected from each site. The bright yellow spots on the (Fig. 1) are the sampling sites. The reference location (R) was the agricultural soils approximately $2.5 \mathrm{~km}$ far from location A. Wind flow direction was considered for the effect of fly ash deposition on the soil. Soil samples were collected from the soil surface to the root zone $(0-30 \mathrm{~cm})$. Soil sampling was done with a stainless-steel spade. All of the samples were put in polythene bags and transported to the laboratory on the day of sampling.

\subsection{Processing of samples}

The composite soil samples were sieved through a $2 \mathrm{~mm}$ sieve, homogenized, a portion of this was air-dried for physical and chemical analysis, another portion was ground to pass through a $1 \mathrm{~mm}$ sieve, adjusting to $45 \%$ of water holding capacity, stored in polythene bags at $4^{\circ} \mathrm{C}$ before soil microbial and enzymatic activities analysis.

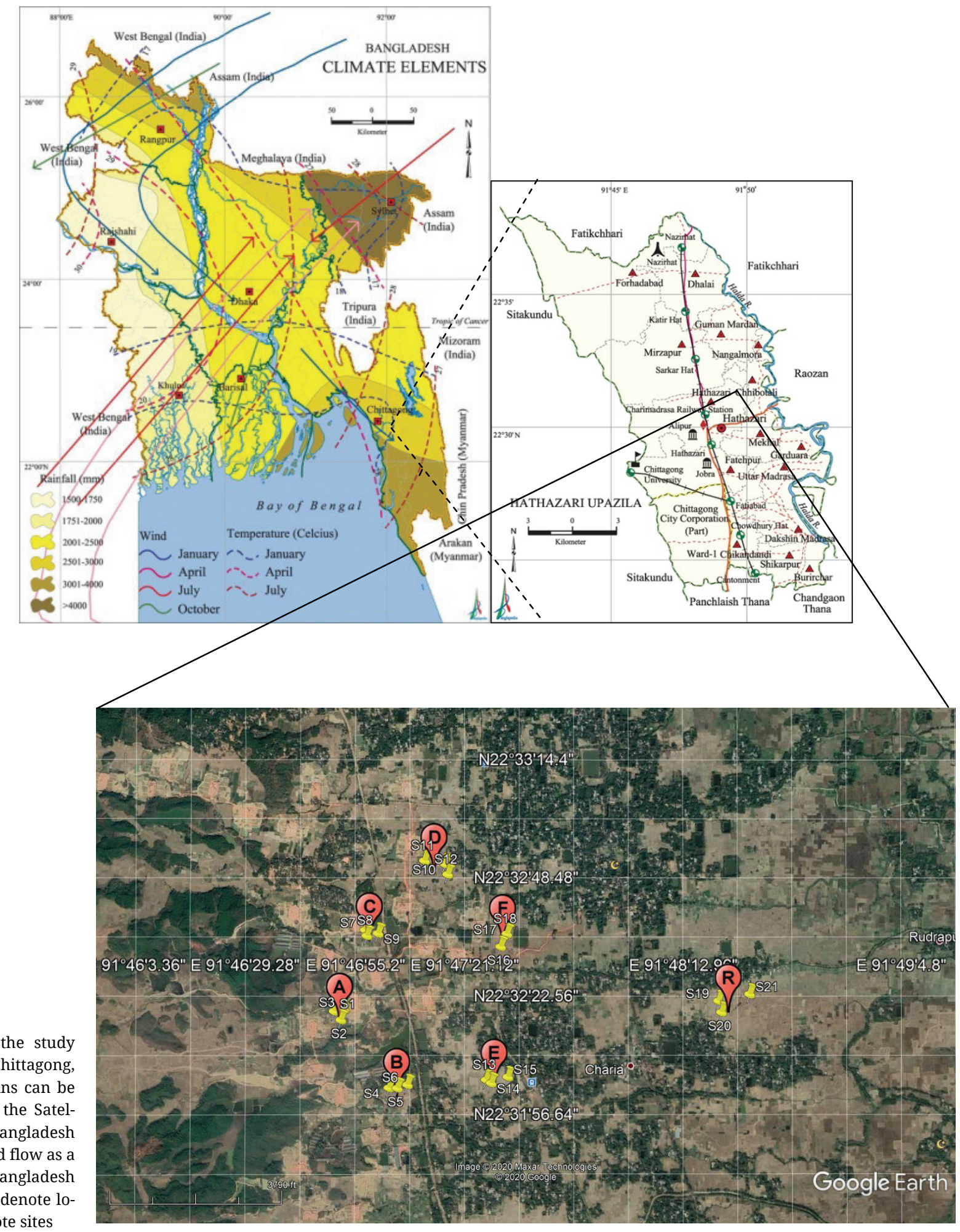

Fig. 1. Location of the study area Hathazari, Chittagong, Bangladesh. Brick kilns can be prominently seen in the Satellite image. Map of Bangladesh also showing the wind flow as a climatic element of Bangladesh (website 1). Balloons denote locations and pins denote sites 


\subsection{Measurement of soil physical and chemical properties}

General soil characteristics were determined following the standard procedures. The $\mathrm{pH}$ of the soil samples was measured by $\mathrm{pH}$ meter at dry soil and distilled water ratio of $1: 5$ as described in Jackson (1973). Particle size distributions of the soils were determined by the hydrometer method (Day, 1965). Textural classes were determined using 'soil automatic texture calculator' by Natural Resources Conservation Service Soils of the United States Department of Agriculture (website 2). The organic carbon (OC) content of the soil samples was determined volumetrically by the wet oxidation method by Nelson and Sommers (1982). Organic matter (OM) content was estimated through the use of an approximate correction factor, the 'Van Bemmelen factor' of 1.724 which is based on the assumption that OM contains $58 \%$ OC. Total nitrogen (TN) content in soil was determined by the Micro-Kjeldahl method following $\mathrm{H}_{2} \mathrm{SO}_{4}$ acid digestion and alkali distillation and available phosphorus (AvP) by the colorimetric method after digestion with hydrofluoric and perchloric acid (Jackson, 1973). The total concentrations of cadmium (Cd) and lead $(\mathrm{Pb})$ were determined by Atomic Absorption Spectrophotometer (Aligent 240) after strong acid digestion (1:1 mixture of concentrated nitric and perchloric acids) of $200 \mathrm{mg}$ of soil samples. The digested samples were filtered and collected in $5 \mathrm{ml}$ of 2.0 M HCL as in Ure (1990).

\subsection{Measurement of soil microbiological properties}

Numbers of total bacteria and fungi in soils were counted using the dilution plate method as described in Johnson and Curl (1972). Nutrient agar (NA) medium was used with bacteria and potato dextrose agar (PDA) medium with fungi. Three plates were used for each soil. The plates were incubated at $28^{\circ} \mathrm{C}$ for 7-10 days and counting made for forming colonies. Soil microbial biomass (MBC) was measured by the method described by Anderson and Ingram (1993). The microbial cells in soil were killed by fumigation with ethanol-free chloroform. Immediately after pre-incubation, duplicate portions soil, $5 \mathrm{~g}$ for each were taken in falcon tubes. One set of samples was fumigated with ethanol-free chloroform for $24 \mathrm{~h}$ at $25^{\circ} \mathrm{C}$ in a sealed desiccator. Non fumigated set of samples in falcon tubes were capped and stored at $8^{\circ} \mathrm{C}$. After fumigant removal, both fumigated and non-fumigated soils were extracted with freshly prepared $0.5 \mathrm{M}$ potassium sulfate at 1:4 ratios and filtered. Dissolved OC in the extracts was determined after dichromate digestion by titrating with $0.03 \mathrm{M}$ acidified ferrous ammonium sulfate. The amount of soil MBC was calculated from the difference between the extracted carbon from chloroform fumigated and non-fumigated samples. Soil microbial activity (MA) was determined by trapping the $\mathrm{CO}_{2}$ in $\mathrm{NaOH}$ which were evolved from the soil during incubation in a closed system (Alef, 1995). The trapped $\mathrm{CO}_{2}$ was determined by measuring electrical conductivity (Rodella and Saboya, 1999). For this purpose, $50 \mathrm{~g}$ (oven-dry basis) moist preincubated (60\% of water holding capacity for 10 days) soil was placed in 1-liter capacity incubation Jars. Ten ml of 1.0 M NaOH solution in $50 \mathrm{ml}$ falcon tubes were placed in each jar as the $\mathrm{CO}_{2}$ trap. A falcon tube with water was added into the jar to maintain the soil moisture. Jars were made airtight immediately. Two jars with $1.0 \mathrm{M} \mathrm{NaOH}$ but without soil were used as controls. All jars were incubated at $25^{\circ} \mathrm{C} . \mathrm{CO}_{2}$ absorbed in traps were analyzed at $1,7,14,30$ days of $\mathrm{NaOH}$ placement. Each time fresh $\mathrm{NaOH}$ solution $(10 \mathrm{ml})$ was replaced to trap $\mathrm{CO}_{2}$ for the next days. In this method, $\mathrm{CO}_{2}$ evolved from each sample was calculated as the difference between the initial and the $\mathrm{CO}_{2}$ concentration after each measurement period. The substrate induced respiration (SIR) of the soils was assessed according to the rate of the maximal initial respiration of the microorganism after the enrichment of the soils with $0.5 \%$ glucose (West and Sparling, 1986). Over the first $2 \mathrm{~h}$, the increase in $\mathrm{CO}_{2}-\mathrm{C}$ is proportional to the size of the initial $\mathrm{MBC}$ concentration. Respiration was determined by trapping the $\mathrm{CO}_{2}$ in $\mathrm{NaOH}$ as in MA.

\subsection{Measurement of soil enzymatic properties}

Soil dehydrogenase activity was determined by the procedure of Casida (1977). Soil samples were suspended in a triphenyl tetrazolium chloride solution and incubated for $6 \mathrm{~h}$ at $37^{\circ} \mathrm{C}$. The triphenyl formazan (TPF) produced was extracted with methanol and measured photometrically at $485 \mathrm{~nm}$. Urease activity was assayed according to the method of Tabatabai and Bremner (1972). After the addition of a buffered urea solution, soil samples were incubated for $2 \mathrm{~h}$ at $37^{\circ} \mathrm{C}$. The filtrated solution was distilled with $\mathrm{MgO}$. The produced $\mathrm{NH}_{4}{ }^{+-} \mathrm{N}$ was collected into a boric acid indicator solution and titrated with diluted $\mathrm{H}_{2} \mathrm{SO}_{4}$ to determine the $\mathrm{NH}_{4}^{+}-\mathrm{N}$. Acid phosphatases activity was measured using the method of Eivazi and Tabatabai (1977). After the addition of a buffered p-nitrophenyl phosphate solution ( $\mathrm{pH}$ 6.5), soil samples were incubated for $1 \mathrm{~h}$ at $37^{\circ} \mathrm{C}$. The p-nitrophenol released by phosphomonoesterase activity was extracted and colored with $\mathrm{NaOH}$ and was measured photometrically at $400 \mathrm{~nm}$. Arylsulfatase activity was measured by the potassium p-nitrophenyl sulfate method (Tabatabai and Bremner, 1970). After the addition of a buffered potassium p-nitrophenyl sulfate (pH 5.8), soil samples were incubated for $1 \mathrm{~h}$ at $37^{\circ} \mathrm{C}$. The P-nitrophenol released by phosphomonoesterase activity was extracted and colored with $\mathrm{NaOH}$ and was measured photometrically at $400 \mathrm{~nm}$.

\subsection{Ecological risk assessment for soil pollution}

The degrees of heavy metal contamination in agricultural soils can be evaluated with a comprehensive potential ecological risk $(P E R)$ index. The sensitivity of the biological community can be expressed by it to the heavy metal stress and indicates the potential ecological risk caused by the overall heavy metal contamination. The equations which were used to calculate $P E R$ are as follows (Guo et al., 2010):

$$
C_{f}^{i}=\frac{C^{i}}{C_{n}^{i}} \quad C_{d}=\sum_{i=1}^{n} C_{f}^{i} \quad E_{r}^{i}=T_{r}^{i} \times C_{f}^{i} \quad P E R \sum_{i=1}^{m} E_{r}^{i}
$$

where: $P E R$ = comprehensive potential ecological risk index, $C_{f}^{i}=$ single heavy metal contamination factor, $C^{i}=$ content of the heavy metal in samples, $C_{n}^{i}=$ background value of the heavy 
metal, $C_{d}=$ degree of contaminations, $E_{r}^{i}=$ potential ecological risk index, $T_{r}^{i}=$ biological toxic factor, the biological factors for cadmium $=30$ and lead $=5$ (Guo et al., 2010; Islam and Hoque 2014).

\subsection{Microbial metabolic quotient}

Stress in the microbial population can be determined by the microbial quotient ( $q \mathrm{Mic}$ ) and metabolic quotient $\left(q \mathrm{CO}_{2}\right)$. Organic carbon in soil generally undergo microbial synthesis and converted to humus. But, in the case of increased stress, more $\mathrm{CO}_{2}$-carbon per unit microbial biomass per unit time is produced to counter stress. Metabolic quotient was calculated from basal respiration at the end of the 30 days' incubation period according to the following equation (Anderson and Domsch, 1990).

$q \mathrm{CO}_{2}=\frac{\mathrm{r}}{\mathrm{MBC}}$

where: $\mathrm{r}=$ respiration rate, $\mathrm{mgC} \cdot \mathrm{g}$ soil $\cdot 24 \mathrm{~h}^{-1}, \mathrm{MBC}=$ soil microbial biomass carbon, $\mathrm{mg}$ biomass $\mathrm{C} \cdot \mathrm{kg}$ soil $^{-1}$.

Microbial quotient representing the ratio of soil MBC to organic carbon expressed as percent (\%) to explore the percent of organic carbon present as microbial biomass carbon (Anderson and Domsch, 1989):

$q \mathrm{MIC}=\frac{\mathrm{MBC}}{\mathrm{OC}}$

where: $q$ Mic = microbial quotient, $\mathrm{MBC}=$ soil microbial biomass carbon, $\mathrm{mg}$ biomass $\mathrm{C} \cdot \mathrm{kg}$ soil- ${ }^{-1}, \mathrm{OC}=$ total organic carbon, $\mathrm{mg} \cdot \mathrm{kg}^{-1}$.

\subsection{Kinetic models related to enzymatic activity}

The inhibition of enzymatic activity by heavy metal was assessed by two kinetic models (Model 1: Equation 4 and Model 2: Equation 5) and a sigmoidal dose-response model (Model 3: Equation 6) using PER (Gao et al., 2010). The 50\% ecological dose $\left(\mathrm{ED}_{50}\right)$ values are calculated for Models 1 and 2 by fitting Equation 7 and for Model 3 by fitting Equation 8:

$$
\begin{aligned}
& \text { Model 1: } \mathrm{v}=\frac{c}{1+b P E R} \\
& \text { Model 2: } \mathrm{v}=\frac{c(1+a P E R)}{1+b P E R} \\
& \text { Model 3: } \mathrm{v}=\frac{x}{1+e^{y(l-z)}} \\
& \mathrm{ED}_{50}=\frac{1}{b} \\
& \mathrm{ED}_{50}=c^{c}
\end{aligned}
$$

where, $\mathrm{ED}_{50}=$ total ecological toxicity coefficients which lead to enzyme activity inhibited by $50 \%, P E R=$ potential ecological risk index under multiple heavy metal pollution in Equation 1, $\mathrm{v}=$ response variable, $\mathrm{a}, \mathrm{b}$ and $\mathrm{c}=$ fitting parameters with positive values and $\mathrm{b}>\mathrm{a}, \mathrm{l}=$ natural logarithm of $P E R, \mathrm{x}=$ uninhibited value of $\mathrm{v}, \mathrm{y}=$ slope factor, $\mathrm{z}=$ natural logarithm of $\mathrm{ED}_{50}$.

\subsection{Statistical analysis}

All the results are expressed on an oven-dry weight basis which was measured with three replications. Correlations between the selected parameters and standard deviation were determined using Microsoft Excel 2016 program. Regression between soil parameters and soil microbial activities and enzyme activities was fitted to linear and exponential functions. The effects of $\mathrm{Cd}$ and $\mathrm{Pb}$ were determined by one-way analysis of variance (ANOVA) and the significance of the parameters was tested using the least significant difference multiple range test at $\mathrm{p}<0.05$. Pared-samples T-test measured for soil samples firstly by considering soil samples all together ( $n=63$ ), secondly by considering mean values representing the sites with different agricultural management $(n=21)$ and thirdly considering specific location types $(n=7)$ by IBM SPSS program. The dendrogram grouping for cluster analysis was performed by IBM SPSS and Principal Component Analysis (PCA) was performed by XLSTAT.

\section{Results and discussion}

A detailed study on soil properties of a cluster of brick kiln in the Charia area, Hathazari, Chittagong district was done and its operation effect on soil properties and microbial biomass and activity as well as soil enzyme activity in the surrounding agricultural area was analyzed to infer the impact of brick kiln emissions.

\subsection{Physical and chemical properties of the agricultural soils}

The soil texture of the agricultural soil was sandy clay loam. This textural class of soil is favorable for agricultural practice in Bangladesh. The percentage of clay ranged from 22.51 to $34.13 \%$ (Table 1). There was no significant difference between reference soil (28.71\%) and agricultural soils (26.10\%) around the brick kiln cluster for average clay content. The $\mathrm{pH}$ values of the samples ranged from 4.15 to 6.30 (Table 1 ), which were very strongly acidic to neutral (Hazelton and Murphy, 2016). Reference soils (average pH 5.84) were moderately acidic in nature. SRDI (2008) reported that the $\mathrm{pH}$ values of the soil series (Lama, Rangamati, Matiranga) of the Hathazari area are strongly acidic in nature. The inherited acidic nature of some of the studied soils can be increased due to fly ash application to the agricultural field which is produced as a byproduct from brick kiln operation (Fatima et al., 2011). The pH of soil samples at agricultural soils varied significantly with each other as well as with the reference sites, so it refers to impact from the brick kiln.

Soil $\mathrm{OM}$ and TN ranged from 0.60 to $1.67 \%$ and 0.10 to $0.23 \%$, respectively under agriculture soils near the brick kiln cluster (Table 1). Reference sites (S19, S20 and S21) and sites S5, S8, S9, S12 and S15 had the higher OM ( $\geq 1.20 \%)$ and TN ( $\geq 0.20 \%)$ contents. The content of $\mathrm{OM}$ at all the sites was nearly uniform, there were no significant differences between average OM content of agricultural soils and reference soils. The overall simi- 
lar value of OM may be due to similar cultivation induced OM decomposition and excessive use of fertilizers in the cultivated field. However, some variations of TN in the same location may be the result of the variation of agricultural practices. Deposition of unburnt hydrocarbon in the form of soot on soil from aerial deposits from brick kilns and vehicles running in ChittagongBandarban highway can also be considered for some contribution of OC content in some sites (Bisht and Neupane, 2015). The AvP content also varied among the agricultural soils (Table 1). The AvP content of the samples was within the range of 2.65 to $13.44 \mathrm{mg} \cdot \mathrm{kg}^{-1}$ in the agricultural soils near brick kiln and of 14.65 $\mathrm{mg} \cdot \mathrm{kg}^{-1}$ (average) in the reference soils. Soils of the agricultural sites (S4, S7, S10, S11, S14, S15 and S16) showed deficient in AvP content as a critical level of AvP is below $7.00 \mathrm{mg} \cdot \mathrm{kg}^{-1}$ (BARC 2012). Regular application of $P$ fertilizer to the agricultural field may be the reason for the irregular pattern of phosphorus to the agricultural sites. Soil pH was highest in site S9 (6.30) in combination with the highest OM (1.67\%) and AvP (0.20\%). Essential nutrient elements $-\mathrm{TN}(\mathrm{r}=0.79, p<0.001)$ and AvP $(\mathrm{r}=0.51$, $p<0.001$ ) were significantly correlated to soil OM content. TN and AvP were significantly correlated to each other $(\mathrm{r}=0.60, \mathrm{p}<$ $0.001)$ and a positive significant $(r=0.67, p<0.001)$ correlation of $\mathrm{OM}$ and $\mathrm{pH}$ was found for the soils (Fig. 2a).

\section{2. $\mathrm{Cd}$ and $\mathrm{Pb}$ in the agricultural soil}

The results of $\mathrm{Cd}$ and $\mathrm{Pb}$ concentration in the soil samples are presented in (Table 1). The concentration of $\mathrm{Cd}$ in agricultural soils of the study area ranged from 0.27 to $1.07 \mathrm{mg} \cdot \mathrm{kg}^{-1}$ and 19.07 to $52.07 \mathrm{mg} \cdot \mathrm{kg}^{-1}$ for $\mathrm{Pb}$. The average concentrations of $\mathrm{Cd}$ and $\mathrm{Pb}$ were 0.64 and $29.97 \mathrm{mg} \cdot \mathrm{kg}^{-1}$ respectively. In reference soils, the values were $0.15 \mathrm{mg} \cdot \mathrm{kg}^{-1}$ soil for $\mathrm{Cd}$ and $8.06 \mathrm{mg} \cdot \mathrm{kg}^{-1}$ soil for $\mathrm{Pb}$. In particular, the mean concentrations of $\mathrm{Cd}$ and $\mathrm{Pb}$ in the study area were 4.3 and 3.7 fold higher than the refer- ence sites, respectively. Therefore, the anthropogenic activities related to brick kiln operation may be responsible for the $\mathrm{Cd}$ and $\mathrm{Pb}$ contamination in the agricultural soils. Heavy metal concentrations in the study region were also compared to the standard values for agricultural soil (Chinese environmental quality standards for soil, $\mathrm{Pb}$ is $250 \mathrm{mg} \cdot \mathrm{kg}^{-1}$ and $\mathrm{Cd}$ is $0.30 \mathrm{mg} \cdot \mathrm{kg}^{-1}$ for dry agricultural soil at $\mathrm{pH}<6.5$, Act no. 220/2004 coll. of laws) (Chen et al., 2018). Comparing the concentrations sites S6, S1, S3, S2, S14, S10, S16, S7, S13 and S4 seem to have a higher contamination of $\mathrm{Cd}$ and $\mathrm{Pb}$ that was attributed to the heavy input of aerial deposits of metal-enriched fumes. The results showed an irregular pattern of the heavy metal ( $\mathrm{Cd}$ and $\mathrm{Pb}$ ) availability in soil samples. The $P E R$ which shows the extent of contamination of the sampling sites indicated moderate to a considerable level of contamination in the agricultural soils around the brick kiln cluster. However, no potential ecological risk was found with reference sites (S19, S20 and S21), for which the sum of toxic units was lower than 40 .

The $\mathrm{pH}$ values of the studied area were naturally acidic. Soil $\mathrm{pH}$ showed a significant negative correlation with $\mathrm{Cd}(\mathrm{r}=-0.65)$ and $\mathrm{Pb}(\mathrm{r}=-0.56)$, which may suggest that $\mathrm{pH}$ influenced the distributions of these metals in soils. For both heavy metals, $\mathrm{Cd}$ and $\mathrm{Pb}$, an inversely proportional relation between their accumulation rate and concentrations of $\mathrm{OM}$ was found (Fig. 2a), which indicates that with an increase in $\mathrm{Cd}$ and $\mathrm{Pb}$ concentration, a significant decrease in the OM of soil was observed, which might be due to low soil biological activity. Furthermore, both $\mathrm{Cd}$ and $\mathrm{Pb}$ accumulation rates in soil decreased with the increasing concentrations of clay in that soil. The correlation between metal concentration in soil and clay content and soil OM depends on the physical and chemical characteristics of the soil, mostly soil $\mathrm{pH}$ and the content and type of clays, the content and type of organic matter and oxides (Orrońo and Lavado, 2009). Rieuwerts et al., (1998) reported that the correlation of heavy metals was found
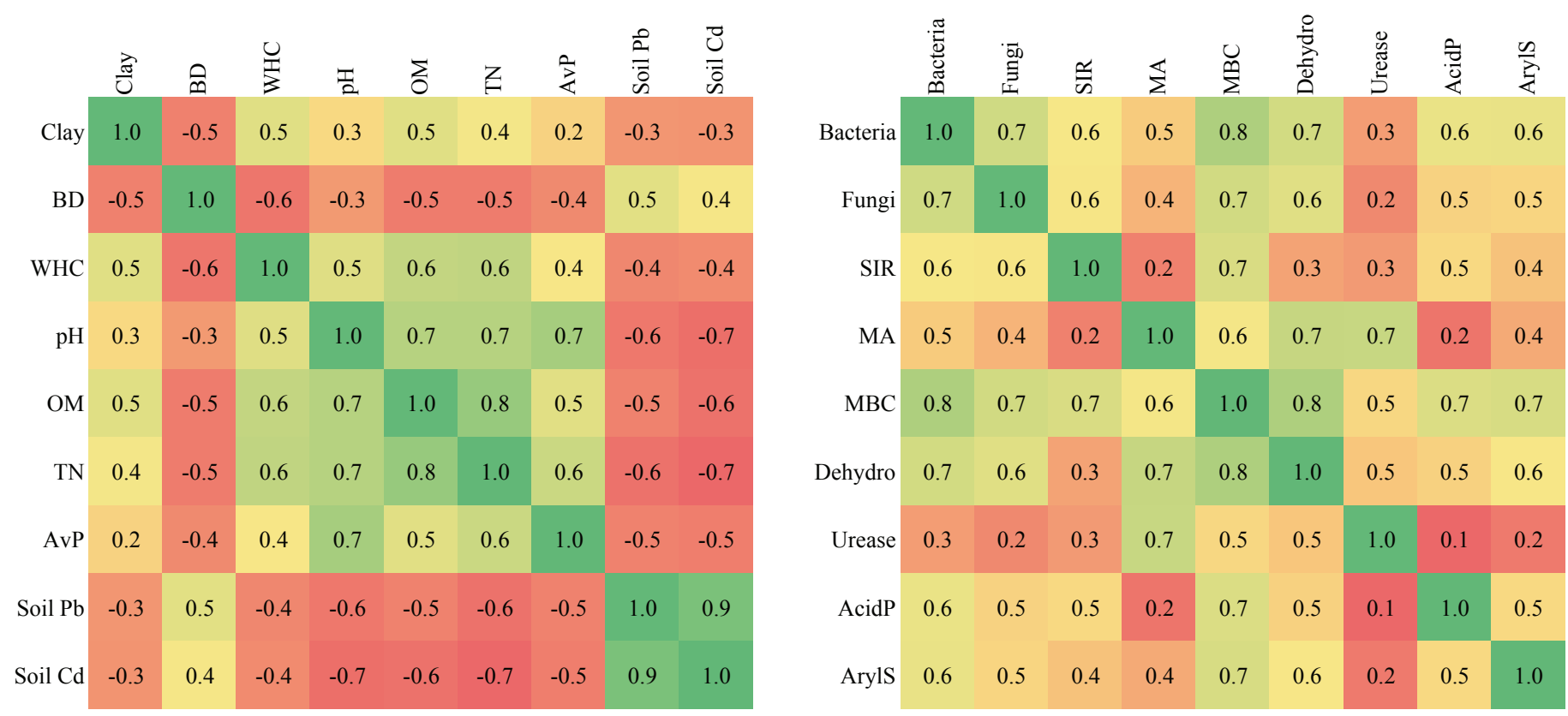

Fig. 2. Pearson's correlation analysis correlating (a) soil physicochemical properties and heavy metals (b) Soil microbiological properties and enzyme activities $(n=63)(p<0.05)$. Green boxes show positive correlations; red boxes show negative correlations 
to be high with Fe-Mn oxides than with SOM in some soils. The influence of clay on $\mathrm{Cd}$ and $\mathrm{Pb}$ accumulation can be negligible or negative (Wieczorek et al., 2018) and metal sorption is more related to clay mineralogy than clay quantity (Orrońo and Lavado, 2009). Accumulation and activity of anthropogenic $\mathrm{Cd}$ and $\mathrm{Pb}$ in the soil also influence by the size and surface area of the emitted particles, differences in speciation and type of binding forms (Rieuwerts et al., 1998). In the case of soil samples, Pb showed strong significant correlations with $\mathrm{Cd}(\mathrm{r}=0.89)$ indicating their associations among themselves and hence, may be originated from a similar source of contamination..

\subsection{Microbiological properties of the agricultural soils}

Different heavy metal stresses which may enter into the soil system by anthropogenic activities can affect soil microorganisms, consequently, negatively affect soil fertility via reduced OM decomposition and nutrient (Sharma et al., 2017). Microbial activities found to be decreased in the highly contaminated agricultural soils and significant negative relations were found between soil $\mathrm{Cd}$ and $\mathrm{Pb}$ contents and microbial numbers and activities (Table 3). The mechanism involved in inactivating and inhibiting soil microbial activity differs for different heavy metals. The number of culturable bacteria ranged from $61 \times 10^{5} \mathrm{CFU} \cdot \mathrm{g}^{-1}$ dry soil to $302 \times 10^{5} \mathrm{CFU} \cdot \mathrm{g}^{-1}$ dry soil in the agricultural soils. The average number of culturable bacteria in the reference soil was $275 \times 10^{5} \mathrm{CFU} \cdot \mathrm{g}^{-1}$ dry soil. The average count was significantly lower in agricultural soil than from reference soil. The number of culturable fungal populations was lower than the bacterial population and it varied between $67 \times 10^{3} \mathrm{CFU} \cdot \mathrm{g}^{-1}$ dry soil to 260 $\mathrm{x} 10^{3} \mathrm{CFU} \cdot \mathrm{g}^{-1}$ dry soil in the agricultural sites (Table 2 ). The highest number of fungi found in the reference soil ( $284 \times 10^{3} \mathrm{CFU} \cdot \mathrm{g}^{-1}$ dry soil). No specific pattern of the effect of brick kiln emission was observed against soil bacteria and fungi but an average decrease in total culturable numbers for the heavy metal contaminated soil samples indicate that $\mathrm{Cd}$ and $\mathrm{Pb}$ inhibit soil microbial population (Chen et al., 2014, Abdu et al., 2017). Bacteria seem to be more sensitive to heavy metal contamination than fungi (soil $\mathrm{Cd}$ and bacteria, $\mathrm{r}=-0.69, \mathrm{p}<0.001$; soil $\mathrm{Cd}$ and fungi, $\mathrm{r}=-0.63$, $\mathrm{p}<0.001$ ) (soil $\mathrm{Pb}$ and bacteria, $\mathrm{r}=-0.66, \mathrm{p}<0.001$; soil $\mathrm{Pb}$ and fungi, $\mathrm{r}=-0.53, \mathrm{p}<0.001$ ) (Table 3 ).

Total MA and SIR of soils were measured as microbial respiration rates (Table 2). The highest SIR was in site S18 (54 mg $\left.\mathrm{CO}_{2} \cdot \mathrm{g}^{-1}\right)$ and the lowest in sites $\mathrm{S} 1\left(7.38 \mathrm{mg} \mathrm{CO} \cdot \mathrm{g}^{-1}\right)$. The average SIR in reference soil was $83.12 \mathrm{mg} \mathrm{CO}_{2} \cdot \mathrm{g}^{-1}$. The brick kilns contribute significantly to the reduction of MA through its operation and emission (Khan et al., 2007). In this study, MA was not found to be significantly affected by brick kiln operation. The highest MA was in site $\mathrm{S} 12\left(28.18 \mathrm{mg} \mathrm{C} \cdot \mathrm{g}^{-1}\right.$ soil $\left.^{2} 24 \mathrm{~h}^{-1}\right)$ and the lowest in sites S1 (12.69 $\mathrm{mg} \mathrm{C} \cdot \mathrm{g}^{-1}$ soil $\left.\cdot 24 \mathrm{~h}^{-1}\right)$. The average MA in reference
Table 2

Microbiological properties (mean \pm SD) of different agricultural soils adjacent to the brick kiln cluster, Hathazari, Chattogram

Each mean is the average of the values obtained for three samples of each soil. Values in the same column followed by the same letter(s) are not significantly different at $\mathrm{p}<0.05$ according to ANOVA.

[CFU = Colony forming unit, SD = Standard deviation]

\begin{tabular}{|c|c|c|c|c|c|}
\hline Sample & $\begin{array}{l}\text { Number } \\
\text { of culturable } \\
\text { Bacteria } \\
\end{array}$ & $\begin{array}{l}\text { Number } \\
\text { of culturable } \\
\text { Fungi }\end{array}$ & $\begin{array}{l}\text { Substrate } \\
\text { induced } \\
\text { respiration }\end{array}$ & $\begin{array}{l}\text { Microbial } \\
\text { activity }\end{array}$ & $\begin{array}{l}\text { Microbial } \\
\text { biomass } \\
\text { carbon }\end{array}$ \\
\hline & $\begin{array}{l}\times 10^{5} \mathrm{CFU} \cdot \mathrm{g}^{-1} \\
\text { dry soil }\end{array}$ & $\begin{array}{l}\times 10^{3} \mathrm{CFU} \cdot \mathrm{g}^{-1} \\
\text { dry soil }\end{array}$ & $\mathrm{mg} \mathrm{CO} \cdot \mathrm{g}^{-1}$ & $\mathrm{mg} \mathrm{CO}{ }_{2}-\mathrm{C} \cdot \mathrm{g}^{-1} \mathrm{day}^{-1}$ & $\mathrm{mg} \mathrm{C} \cdot \mathrm{kg}^{-1}$ \\
\hline S1 & $100.00 \pm 1.00^{b}$ & $86.30 \pm 0.61^{\mathrm{b}}$ & $7.38 \pm 0.43^{\mathrm{a}}$ & $12.69 \pm 0.63^{\mathrm{a}}$ & $130.00 \pm 0.00^{\mathrm{a}}$ \\
\hline S2 & $80.00 \pm 1.00^{\mathrm{ab}}$ & $196.67 \pm 2.89^{\mathrm{gh}}$ & $13.05 \pm 0.71^{\text {cdef }}$ & $21.45 \pm 0.56^{\mathrm{h}}$ & $745.33 \pm 47.44^{\mathrm{ef}}$ \\
\hline S3 & $60.67 \pm 0.58^{a}$ & $66.67 \pm 12.58^{\mathrm{a}}$ & $17.20 \pm 1.11^{\mathrm{h}}$ & $13.00 \pm 0.51^{\mathrm{a}}$ & $338.70 \pm 44.47^{\mathrm{abc}}$ \\
\hline S4 & $110.67 \pm 1.15^{\mathrm{c}}$ & $248.33 \pm 38.19^{\mathrm{ij}}$ & $10.00 \pm 2.00^{\mathrm{ab}}$ & $19.46 \pm 0.41^{\mathrm{fg}}$ & $687.33 \pm 58.35^{\mathrm{def}}$ \\
\hline S5 & $155.00 \pm 10.00^{\mathrm{def}}$ & $260.00 \pm 10.00^{\mathrm{jk}}$ & $10.00 \pm 2.00^{\mathrm{ab}}$ & $17.09 \pm 0.55^{\mathrm{cd}}$ & $1500.00 \pm 300.00^{\mathrm{g}}$ \\
\hline S6 & $150.00 \pm 10.00^{\mathrm{de}}$ & $210.00 \pm 10.00^{\mathrm{h}}$ & $9.33 \pm 1.15^{\mathrm{ab}}$ & $13.48 \pm 0.53^{\mathrm{a}}$ & $300.00 \pm 100.00^{\mathrm{ab}}$ \\
\hline S7 & $138.33 \pm 7.64^{\mathrm{d}}$ & $170.00 \pm 5.00^{\mathrm{de}}$ & $11.33 \pm 1.15^{\mathrm{bcd}}$ & $19.13 \pm 0.35^{\mathrm{efg}}$ & $600.00 \pm 200.00^{\text {cde }}$ \\
\hline S8 & $301.67 \pm 12.58^{j}$ & $251.33 \pm 2.08^{\mathrm{ij}}$ & $8.00 \pm 0.00^{\mathrm{a}}$ & $20.10 \pm 1.19^{g}$ & $1600.00 \pm 200.00^{\mathrm{g}}$ \\
\hline S9 & $231.67 \pm 7.64^{\mathrm{i}}$ & $178.33 \pm 2.89^{\text {def }}$ & $10.00 \pm 2.00^{\mathrm{ab}}$ & $22.91 \pm 0.63^{\mathrm{i}}$ & $1666.67 \pm 115.47^{g}$ \\
\hline S10 & $173.33 \pm 7.64^{\mathrm{fg}}$ & $166.67 \pm 7.64^{\mathrm{de}}$ & $12.67 \pm 1.15^{\text {cde }}$ & $15.32 \pm 0.65^{b}$ & $566.67 \pm 208.17^{\text {bcde }}$ \\
\hline S11 & $200.00 \pm 20.00^{\mathrm{h}}$ & $183.34 \pm 0.15^{\text {efg }}$ & $13.33 \pm 1.15^{\text {def }}$ & $26.63 \pm 1.37^{j}$ & $900.00 \pm 100.00^{f}$ \\
\hline S12 & $163.33 \pm 25.17^{\text {efg }}$ & $160.00 \pm 5.00^{\mathrm{d}}$ & $14.00 \pm 2.00^{\mathrm{efg}}$ & $28.18 \pm 0.83^{\mathrm{k}}$ & $1600.00 \pm 200.00^{\mathrm{g}}$ \\
\hline S13 & $105.00 \pm 13.23^{\mathrm{c}}$ & $203.00 \pm 2.65^{\mathrm{h}}$ & $15.33 \pm 1.15^{\mathrm{fgh}}$ & $19.04 \pm 0.58^{\mathrm{efg}}$ & $679.67 \pm 57.77^{\mathrm{def}}$ \\
\hline S14 & $80.00 \pm 10.00^{\mathrm{ab}}$ & $106.67 \pm 0.58^{c}$ & $14.00 \pm 2.00^{\mathrm{efg}}$ & $15.41 \pm 0.61^{b}$ & $466.67 \pm 152.75^{\mathrm{bcd}}$ \\
\hline S15 & $206.67 \pm 30.55^{h}$ & $194.00 \pm 3.61^{\mathrm{fgh}}$ & $16.00 \pm 2.00^{\mathrm{gh}}$ & $23.45 \pm 0.31^{\mathrm{i}}$ & $900.00 \pm 300.00^{f}$ \\
\hline S16 & $106.67 \pm 1.53^{c}$ & $81.00 \pm 9.54^{\mathrm{ab}}$ & $17.33 \pm 1.15^{\mathrm{h}}$ & $15.27 \pm 1.67^{\mathrm{b}}$ & $300.00 \pm 100.00^{\mathrm{ab}}$ \\
\hline S17 & $113.00 \pm 1.00^{c}$ & $165.00 \pm 5.00^{\mathrm{de}}$ & $10.67 \pm 2.31^{\mathrm{bc}}$ & $16.55 \pm 0.55^{b c}$ & $950.00 \pm 20.00^{\mathrm{f}}$ \\
\hline S18 & $185.00 \pm 22.91^{\mathrm{gh}}$ & $240.00 \pm 10.00^{\mathrm{i}}$ & $54.00 \pm 0.00^{\mathrm{i}}$ & $18.26 \pm 0.07^{\mathrm{def}}$ & $806.67 \pm 66.58^{\mathrm{ef}}$ \\
\hline S19 & $281.33 \pm 0.58^{j}$ & $295.33 \pm 1.53^{\mathrm{m}}$ & $76.40 \pm 0.40^{j}$ & $18.00 \pm 1.14^{\mathrm{de}}$ & $1765.67 \pm 152.17^{g}$ \\
\hline S20 & $252.67 \pm 4.16^{\mathrm{i}}$ & $272.00 \pm 2.00^{\mathrm{kl}}$ & $87.27 \pm 1.10^{\mathrm{k}}$ & $23.09 \pm 0.00^{\mathrm{i}}$ & $2314.37 \pm 100.17^{\mathrm{h}}$ \\
\hline S21 & $290.00 \pm 10.00^{j}$ & $283.33 \pm 2.89^{\mathrm{Im}}$ & $85.69 \pm 1.48^{\mathrm{k}}$ & $22.55 \pm 0.00^{\mathrm{hi}}$ & $2513.33 \pm 66.58^{\mathrm{h}}$ \\
\hline
\end{tabular}


Table 3

Correlation coefficients among soil physicochemical characteristics, $\mathrm{Pb}$ and $\mathrm{Cd}$ concentrations and soil microbial and enzymatic properties
${ }^{a}$ Correlation is significant at the 0.001 level

${ }^{\mathrm{b}}$ Correlation is significant at the 0.01 level

${ }^{\mathrm{c}}$ Correlation is significant at the 0.05 level

$[P E R=$ comprehensive potential ecological risk index, SIR = Substrate induced respiration, MA = Microbial activity, $\mathrm{MBC}=$ Microbial biomass carbon, AcidP $=$ Acid phosphatase, ArylS = Arylsulfatase]

\begin{tabular}{|c|c|c|c|c|}
\hline $\begin{array}{l}\text { Soil } \\
\text { properties }\end{array}$ & $\begin{array}{l}\text { Soil microbial and } \\
\text { enzymatic properties }\end{array}$ & Correlation equation & $\mathrm{R}^{2}$ & $\mathrm{r}$ \\
\hline \multirow[t]{9}{*}{$\mathrm{pH}$} & Bacteria & $y=66.75 x-180.85$ & 0.31 & $0.55^{\mathrm{a}}$ \\
\hline & Fungi & $y=37.06 x-1.28$ & 0.11 & $0.34^{\mathrm{b}}$ \\
\hline & SIR & $y=13.70 x-46.77$ & 0.10 & $0.32^{\mathrm{b}}$ \\
\hline & MA & $y=2.66 x+5.29$ & 0.14 & $0.37^{\mathrm{b}}$ \\
\hline & $\mathrm{MBC}$ & $y=811.21 x-3200$ & 0.52 & $0.72^{\mathrm{a}}$ \\
\hline & Dehydrogenase & $y=217.39 x-681.88$ & 0.48 & $0.69^{\mathrm{a}}$ \\
\hline & Urease & $y=10.48 x-19.13$ & 0.14 & $0.38^{\mathrm{b}}$ \\
\hline & AcidP & $y=77.00 x-244.68$ & 0.34 & $0.58^{\mathrm{a}}$ \\
\hline & Aryls & $y=14.42 .42 x-25.89$ & 0.43 & $0.66^{\mathrm{a}}$ \\
\hline \multirow[t]{9}{*}{$\mathrm{OM}$} & Bacteria & $y=131.57 x+29.75$ & 0.27 & $0.52^{\mathrm{a}}$ \\
\hline & Fungi & $y=123.23 x+63.76$ & 0.28 & $0.53^{\mathrm{a}}$ \\
\hline & SIR & $y=10.57 x+13.49$ & 0.01 & $0.12^{\text {ns }}$ \\
\hline & MA & $y=9.35 x+9.42$ & 0.39 & $0.62^{\mathrm{a}}$ \\
\hline & $\mathrm{MBC}$ & $y=1623.6 x-665.03$ & 0.47 & $0.68^{\mathrm{a}}$ \\
\hline & Dehydrogenase & $y=449.72 x-17.69$ & 0.46 & $0.68^{\mathrm{a}}$ \\
\hline & Urease & $y=31.37 x+2.87$ & 0.29 & $0.54^{\mathrm{a}}$ \\
\hline & AcidP & $y=101.03 x+50.88$ & 0.13 & $0.36^{\mathrm{b}}$ \\
\hline & Aryls & $y=27.54 x+20.54$ & 0.35 & $0.60^{\mathrm{a}}$ \\
\hline \multirow[t]{9}{*}{ Clay } & Bacteria & $y=7.35 x-26.56$ & 0.20 & $0.44^{\mathrm{a}}$ \\
\hline & Fungi & $y=5.01 x+59.95$ & 0.11 & $0.33^{\mathrm{b}}$ \\
\hline & SIR & $y=0.91 x+0.51$ & 0.02 & $0.15^{\text {ns }}$ \\
\hline & MA & $y=0.31 x+10.90$ & 0.10 & $0.32^{\mathrm{b}}$ \\
\hline & $\mathrm{MBC}$ & $y=76.86 x-998.10$ & 0.25 & $0.50^{\mathrm{a}}$ \\
\hline & Dehydrogenase & $y=17.80 x-18.64$ & 0.17 & $0.41^{\mathrm{a}}$ \\
\hline & Urease & $y=0.76 x+15.66$ & 0.04 & $0.20^{\mathrm{ns}}$ \\
\hline & AcidP & $y=2.72 x+84.32$ & 0.02 & $0.15^{\mathrm{ns}}$ \\
\hline & Aryls & $y=1.50 x+9.62$ & 0.25 & $0.50^{\mathrm{a}}$ \\
\hline \multirow[t]{9}{*}{ Soil Pb } & Bacteria & $y=-4.27 x+280.57$ & 0.44 & $-0.66^{a}$ \\
\hline & Fungi & $y=-3.10 x+274.58$ & 0.28 & $-0.53^{a}$ \\
\hline & SIR & $y=-1.58 x+66.86$ & 0.47 & $-0.68^{\mathrm{a}}$ \\
\hline & MA & $y=-0.22 x+25.09$ & 0.34 & $-0.58^{a}$ \\
\hline & $\mathrm{MBC}$ & $y=-49.55 x+2345.90$ & 0.67 & $-0.82^{\mathrm{a}}$ \\
\hline & Dehydrogenase & $y=-11.41 x+754.10$ & 0.46 & $-0.68^{a}$ \\
\hline & Urease & $y=-0.75 x+55.52$ & 0.26 & $-0.51^{\mathrm{a}}$ \\
\hline & AcidP & $y=-4.10 x+265.55$ & 0.33 & $-0.58^{\mathrm{a}}$ \\
\hline & Aryls & $y=-0.63 x+66.04$ & 0.29 & $-0.54^{\mathrm{a}}$ \\
\hline \multirow[t]{9}{*}{ Soil Cd } & Bacteria & $y=-168.90 x+261.74$ & 0.48 & $-0.69^{a}$ \\
\hline & Fungi & $y=-138.75 x+270.02$ & 0.39 & $-0.63^{a}$ \\
\hline & SIR & $y=-48.96 x+52.20$ & 0.32 & $-0.56^{\mathrm{a}}$ \\
\hline & MA & $y=-11.03 x+25.36$ & 0.59 & $-0.77^{\mathrm{a}}$ \\
\hline & $\mathrm{MBC}$ & $y=-1910.10 x+2099.00$ & 0.71 & $-0.84^{\mathrm{a}}$ \\
\hline & Dehydrogenase & $y=-543.88 x+756.32$ & 0.74 & $-0.86^{\mathrm{a}}$ \\
\hline & Urease & $y=-33.069 x+54.11$ & 0.35 & $-0.60^{\mathrm{a}}$ \\
\hline & AcidP & $y=-133.57 x+231.22$ & 0.25 & $-0.50^{\mathrm{a}}$ \\
\hline & Aryls & $y=-27.42 x+64.60$ & 0.38 & $-0.62^{\mathrm{a}}$ \\
\hline \multirow[t]{9}{*}{ PER } & Bacteria & $y=-0.75 x+265.74$ & 0.49 & $-0.71^{\mathrm{a}}$ \\
\hline & Fungi & $y=-0.61 x+272.38$ & 0.39 & $-0.63^{\mathrm{a}}$ \\
\hline & SIR & $y=-0.22 x+54.14$ & 0.34 & $-0.58^{\mathrm{a}}$ \\
\hline & MA & $y=-0.05 x+25.49$ & 0.57 & $-0.76^{a}$ \\
\hline & $\mathrm{MBC}$ & $y=-8.53 x+2147.10$ & 0.72 & $-0.86^{a}$ \\
\hline & Dehydrogenase & $y=-2.38 x+763.86$ & 0.72 & $-0.85^{\mathrm{a}}$ \\
\hline & Urease & $y=-0.15 x+54.70$ & 0.35 & $-0.59^{a}$ \\
\hline & AcidP & $y=-0.61 x+236.04$ & 0.26 & $-0.61^{\mathrm{a}}$ \\
\hline & Aryls & $y=-0.12 x+65.11$ & 0.38 & $-0.63^{\mathrm{a}}$ \\
\hline
\end{tabular}


soil was $21.21 \mathrm{mg} \mathrm{C} \cdot \mathrm{g}^{-1}$ soil $\cdot 24 \mathrm{~h}^{-1}$. There was no significant difference between reference and agricultural soils for average MA content. The activity and biomass of soil microbes are closely related to soil fertility and environmental quality. There was a significant difference between agricultural soils near brick kiln and reference soil with the MBC. The amount of MBC in the agricultural soil samples near brick kiln ranged from 130.00 to $1666.67 \mathrm{mg}$ biomass $\mathrm{C} \cdot \mathrm{kg}$ soil $^{-1}$, which were lower values than those of the average values of reference soils $(2197.79 \mathrm{mg}$ biomass $\mathrm{C} \cdot \mathrm{kg}$ soil $^{-1}$ ).

Several studies reported a decrease in the number of culturable bacteria and fungi with increasing levels of heavy metal contamination (Yuan et al., 2015; Srivastava et al., 2017). According to Ali et al., (2019), the way heavy metals act depends on their type and rate. $\mathrm{Pb}$ doses above $50 \mathrm{mg} \cdot \mathrm{kg}^{-1}$ decreased the count of both bacteria and fungi. Khan et al., (2008) showed the inhibitory effect of high $\mathrm{Cd}$ and $\mathrm{Pb}$ concentrations on soil MBC. Heavy metals decrease $\mathrm{MBC}$ and reduce their activity in the soil (Wyszkowska et al., 2008). Soil microbial biomass carbon is a sensitive parameter and can be used as an indicator of changes in OM composition (Yang et al., 2006). The decrease in MBC caused by a high level of heavy metal contamination found at the sites agrees with Wang et al., (2007) and Srivastava et al., (2017). The synthesis of MBC in soils polluted by heavy metals can be less effective than in non-polluted soils due to the stress caused by heavy metals. Yang et al., (2006) stated that $\mathrm{Cd}$ and $\mathrm{Pb}$ cause disorders in the soil MA and depress the MBC of microorganisms.

Microbial indices are useful quantitative tool to assess the effects of anthropogenic stress or disturbance on the soil microbial community. The qMic values decreased, expressing the maintenance energy, as the amount of heavy metal in soil increased. The $q$ Mic value was the highest in site S8 $(2.26 \%)$ and the lowest in S1 (0.34\%). In reference soil, the average amount was $3.14 \%$. To survive in stress, soil microorganisms reduce the conversion of substrate into new $\mathrm{MBC}$ and other metabolic processes, therefore $q$ Mic decreased (Fig. 3). A reduction of this ratio as a result of metal pollution has been reported from other studies (Anderson and Domsch, 1989; Brookes, 1995). Soil microorganisms develop protective measures to adapt in long-term heavy metal pollution by physical exclusion by exopolymers, intracellular sequestration with low molecular weight compounds and precipitation of metals as phosphates, carbonates, and sulfides (Yang et al., 2006; Wang et al., 2007). This kind of cellular activity requires huge energy that increases the demand for maintenance energy. Therefore, $q$ Mic also shows the survival capacity of soil microorganisms. Soil pollution due to heavy metal contamination is a serious problem because tolerant microorganisms can bioaccumulate heavy metals that directly affect the food chain to human health (Zhuang et al., 2009). On the other hand, soil microorganisms under environmental stress shift more energies from growth and reproduction to maintenance and survival, leading to an increase of $q \mathrm{CO}_{2}$ (Zhao et al., 2020). Our results show that the $q \mathrm{CO}_{2}$ increased markedly with increasing heavy metal concentration (Fig. 3). $q \mathrm{CO}_{2}$ was the highest in $\mathrm{S} 1$ (9.76 $\left.\mathrm{mg} \mathrm{CO}_{2}-\mathrm{C} \cdot \mathrm{mg}^{-1} \mathrm{Cmic}^{-1} \mathrm{~h}^{-1} \times 10^{-4}\right)$. In reference soil, average $q \mathrm{CO}_{2}$ was $0.97 \mathrm{mg} \mathrm{CO}-\mathrm{C} \cdot \mathrm{mg}^{-1} \mathrm{Cmic} \cdot \mathrm{h}^{-1} \times 10^{-4}$. According to the finding, $q \mathrm{CO}_{2}$ was generally lower in reference soil compared to the average agricultural soils $\left(3.22 \mathrm{mg} \mathrm{CO}-\mathrm{C} \cdot \mathrm{mg}^{-1} \mathrm{Cmic}^{-1} \times\right.$ $\left.10^{-4}\right)$ near the brick kiln cluster. Reference soils were free from the negative impact of anthropogenic activities during the study period. Liao and Xie (2007) and Zhang et al., (2008) also found the $q \mathrm{CO}_{2}$ as a good indicator of the negative impact of the heavy metal pollution on the soil microorganisms. Correlation study also demonstrated that $q \mathrm{CO}_{2}$ was negatively correlated with soil $\mathrm{MBC}$, number and activity but $q \mathrm{CO}_{2}$ was significantly positively correlated with heavy metals (soil $\mathrm{Cd}$ and soil $\mathrm{Pb}$ ) (soil $\mathrm{Cd}$ and $q \mathrm{CO}_{2}, \mathrm{r}=0.68, \mathrm{p}<0.001$; soil $\mathrm{Pb}$ and $\left.\mathrm{qCO}_{2}, \mathrm{r}=0.68, \mathrm{p}<0.001\right)$.

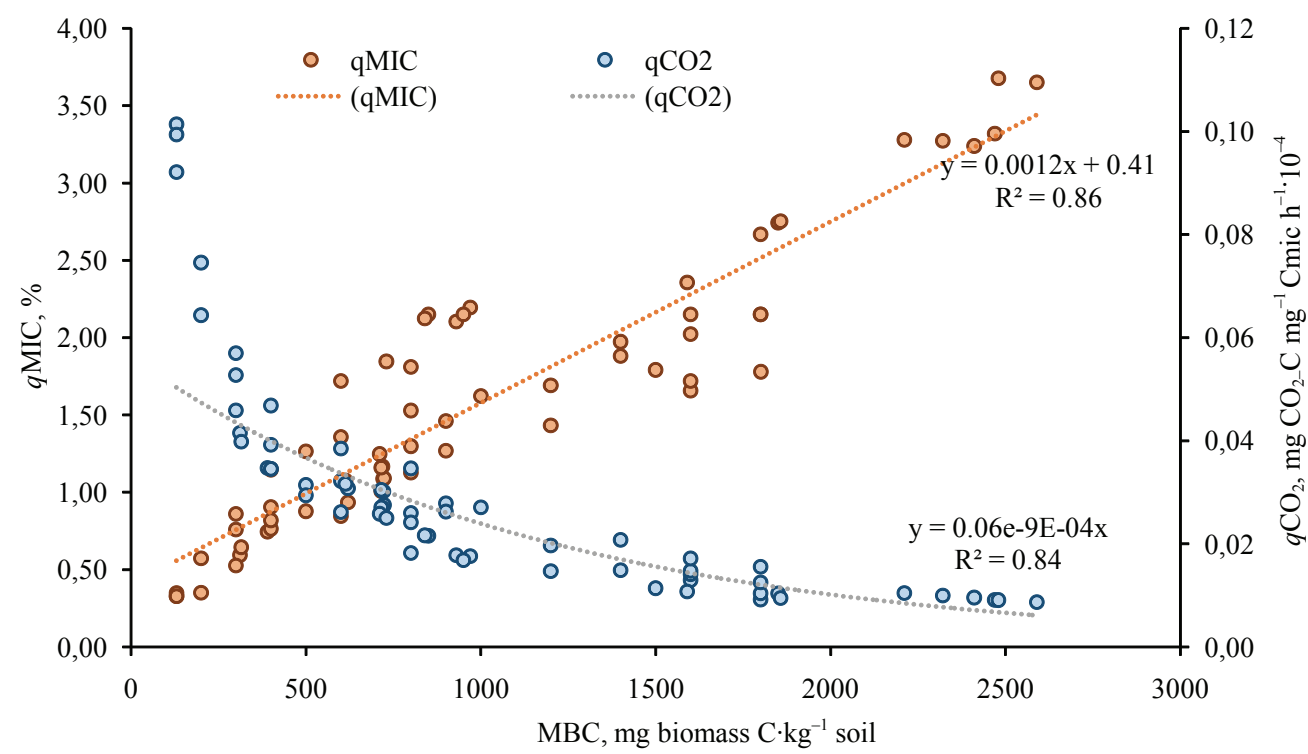

Fig. 3. Relationship of microbial biomass carbon (MBC) and microbial indices ( $q \mathrm{MIC}$ and $\left.q \mathrm{CO}_{2}\right)$ in agricultural soils beside brick kiln cluster, Hathazari, Chattogram. Regression equation, line of the best fit and $\mathrm{R}^{2}$ is shown 


\subsection{Enzymatic properties of the agricultural soils}

Soil enzymes are biological active soil components that have an intimate association with physicochemical and biological soil characteristics (Shukla and Varma, 2011). Soil enzyme activity is widely used as a biological indicator to assess soil contamination. Generally, high enzyme activity represents good soil quality (Fazekašová and Fazekaš, 2020). The dehydrogenase, urease, acid phosphatase and arylsulfatase, enzymes involved in the $\mathrm{C}-\mathrm{N}-\mathrm{P}-\mathrm{S}$ cycle in soil varied widely among the soils studied. The results showed that the average enzymatic activities in agricultural soils were lower than the reference sites. The level of enzyme activity varied in a wide range and for dehydrogenase amounted 94.00 to $718.00 \mathrm{mg}$ formazan $\cdot \mathrm{kg} \mathrm{soil}{ }^{-1} 24 \mathrm{~h}^{-1}$, for urease 14.29 to $65.71 \mathrm{mg} \mathrm{NH}-\mathrm{N} \cdot \mathrm{kg}$ soil $\cdot 2 \mathrm{~h}^{-1}$, for acid phosphatase 56.27 to $318.57 \mathrm{mg}$ p- nitrophenol kg soil ${ }^{-1} \mathrm{~h}^{-1}$, and for arylsulfatase 25.64 to $70.87 \mathrm{mg}$ p- nitrophenol $\mathrm{kg} \mathrm{soil}^{-1} \mathrm{~h}^{-1}$ (Table 4). On the reference sites mean concentration of dehydrogenase, urease, acid phosphatase and arylsulfatase was $616.22 \mathrm{mg}$ formazan $\cdot \mathrm{kg}$ soil $^{-1} 24 \mathrm{~h}^{-1}, 47.38 \mathrm{mg} \mathrm{NH}_{4}-\mathrm{N} \cdot \mathrm{kg}$ soil $\cdot 2 \mathrm{~h}^{-1}, 264.22 \mathrm{mg}$ p- nitrophenol $\mathrm{kg} \mathrm{soil}^{-1} \mathrm{~h}^{-1}$, and $64.68 \mathrm{mg} \mathrm{p}$ - nitrophenol kg soil ${ }^{-1} \mathrm{~h}^{-1}$ respectively. A significant positive correlation $(p<0.001)$ between dehydrogenase, urease, acid phosphatase and arylsulfatase was found in this study (Fig. 2b). Agricultural soils with high heavy metal concentration showed reduced soil enzyme activities. $\mathrm{Cd}$ and $\mathrm{Pb}$ had shown a very high significant negative correlation with the enzymes- dehydrogenase, urease, acid phosphatase and arylsul- fatase (Table 3). Soil enzyme activities are sensitive to the high level of heavy metals (Wang et al., 2008; Xian et al., 2015; Srivastava et al., 2017). The application of different rates of $\mathrm{Cd}, \mathrm{Pb}$, and $\mathrm{Cd} / \mathrm{Pb}$ mixture in soil reduced the activities of acid phosphatase, urease and MBC in comparison to reference soil (Pan and Yu, 2011). All enzyme activities can occur extracellularly along with or within a living cell whereas dehydrogenase activity only acts inside a living cell (Garcýa-Gil et al., 2000; Wang et al., 2007). Therefore, microbial activity inhibited by heavy metal stresses directly express the less dehydrogenase activity.

$\mathrm{ED}_{50}$ value is used to measure the sensitivity of an ecosystem to stress. When a basic ecological function is reduced to $50 \%$ for external stress, the stress is labelled as extreme for its continued functioning. Table 5 shows the $\mathrm{ED}_{50}$ values for the four enzyme activities as measured for the heavy metal contaminated agricultural soils and the best fit model for $\mathrm{ED}_{50}$ values was selected from higher $\mathrm{R}^{2}$ values from the regression analysis. Studies on the impact of toxic metals on soil enzyme showed that enzyme activities in a stressed ecosystem would be always less than $100 \%$ of the reference value. Model 1 was a full inhibition model. Model 2 was a partial inhibition model, suggesting that a fraction of the enzymatic activities was not inhibited by heavy metal contamination to the soil. Model 3 indicates that the relationship between enzyme activity and the toxicity coefficient is sigmoidal dose. It is very hard to interpret the exact reason for the decrease in soil enzyme activities as it may be due to a direct metal inhibition to enzymes or a lower synthesis and re-
Table 4

Soil enzymes involved in soil $\mathrm{C}$ (dehydrogenase), $\mathrm{N}$ (urease), $\mathrm{P}$ (acid phosphatase) and S (arylsulfatase) (mean \pm SD) turnover in soils in different agricultural soils adjacent to the brick kiln cluster, Hathazari, Chattogram

Each mean is the average of the values obtained for three samples of each soil. Values in the same column followed by the same letter(s) are not significantly different at $\mathrm{p}<0.05$ according to ANOVA.

\begin{tabular}{|c|c|c|c|c|}
\hline \multirow[t]{2}{*}{ Sample } & Dehydrogenase & Urease & Acid Phosphatase & Arylsulfatase \\
\hline & $\begin{array}{l}\mathrm{mg} \text { formazan } \cdot \mathrm{kg} \mathrm{soil}^{-1} \\
24 \mathrm{~h}^{-1}\end{array}$ & $\mathrm{mg} \mathrm{NH}_{4}-\mathrm{N} \cdot \mathrm{kg}$ soil $\cdot 2 \mathrm{~h}^{-1}$ & $\begin{array}{l}\text { mg p- nitrophenol } \\
\mathrm{kg} \mathrm{soil}^{-1} \mathrm{~h}^{-1}\end{array}$ & $\begin{array}{l}\mathrm{mg} \mathrm{p} \text { - nitrophenol } \\
\mathrm{kg} \text { soil }{ }^{-1} \mathrm{~h}^{-1}\end{array}$ \\
\hline S1 & $140.33 \pm 4.73^{\mathrm{a}}$ & $15.24 \pm 0.82^{\mathrm{a}}$ & $81.64 \pm 0.30^{\mathrm{a}}$ & $52.52 \pm 6.83^{\text {ef }}$ \\
\hline S2 & $566.00 \pm 22.61^{\mathrm{i}}$ & $35.00 \pm 0.71^{\mathrm{e}}$ & $123.72 \pm 5.77^{\mathrm{ab}}$ & $58.63 \pm 9.95^{\mathrm{fg}}$ \\
\hline S3 & $139.00 \pm 43.14^{\mathrm{a}}$ & $15.00 \pm 0.71^{\mathrm{a}}$ & $147.71 \pm 2.88^{\mathrm{ab}}$ & $41.88 \pm 4.04^{\mathrm{cd}}$ \\
\hline S4 & $425.67 \pm 18.61^{\mathrm{f}}$ & $35.00 \pm 0.71^{\mathrm{e}}$ & $80.04 \pm 1.08^{\mathrm{a}}$ & $41.45 \pm 3.13^{\mathrm{cd}}$ \\
\hline S5 & $465.00 \pm 15.10^{\mathrm{gh}}$ & $29.05 \pm 0.82^{\mathrm{d}}$ & $207.76 \pm 13.95^{\text {bcde }}$ & $59.95 \pm 1.31^{\mathrm{gh}}$ \\
\hline S6 & $254.67 \pm 13.58^{c}$ & $20.95 \pm 0.82^{b}$ & $93.41 \pm 1.12^{\mathrm{a}}$ & $34.23 \pm 0.53^{b}$ \\
\hline S7 & $320.67 \pm 0.58^{\mathrm{d}}$ & $15.00 \pm 0.71^{\mathrm{a}}$ & $7695.00 \pm 21.54^{\mathrm{a}}$ & $51.49 \pm 1.75^{\mathrm{e}}$ \\
\hline S8 & $697.33 \pm 2.52^{\mathrm{k}}$ & $15.00 \pm 0.71^{\mathrm{a}}$ & $306.56 \pm 11.01^{\mathrm{f}}$ & $62.47 \pm 4.02^{\mathrm{gh}}$ \\
\hline S9 & $684.67 \pm 1.53^{\mathrm{k}}$ & $65.00 \pm 0.71^{j}$ & $175.26 \pm 7.34^{\mathrm{abcd}}$ & $63.53 \pm 0.05^{\mathrm{gh}}$ \\
\hline S10 & $359.33 \pm 4.16^{\mathrm{e}}$ & $30.00 \pm 1.43^{\mathrm{d}}$ & $100.80 \pm 19.47^{a}$ & $37.88 \pm 4.02 \mathrm{bc}$ \\
\hline S11 & $568.67 \pm 23.12^{\mathrm{i}}$ & $55.00 \pm 0.71^{\mathrm{h}}$ & $97.33 \pm 21.73^{\mathrm{a}}$ & $33.27 \pm 1.49^{b}$ \\
\hline S12 & $634.67 \pm 9.02^{j}$ & $50.00 \pm 1.43^{g}$ & $124.33 \pm 1.87^{\mathrm{ab}}$ & $47.25 \pm 2.83^{\text {de }}$ \\
\hline S13 & $333.33 \pm 0.58^{\text {de }}$ & $50.00 \pm 1.43^{g}$ & $135.51 \pm 28.20^{\mathrm{ab}}$ & $33.09 \pm 5.53^{\mathrm{b}}$ \\
\hline S14 & $153.67 \pm 9.29^{\mathrm{a}}$ & $40.00 \pm 1.43^{\mathrm{f}}$ & $118.75 \pm 5.51^{\mathrm{ab}}$ & $25.70 \pm 0.07^{\mathrm{a}}$ \\
\hline S15 & $478.67 \pm 1.15^{\mathrm{h}}$ & $50.00 \pm 1.43^{g}$ & $145.26 \pm 11.31^{\mathrm{ab}}$ & $66.49 \pm 3.95^{\mathrm{h}}$ \\
\hline S16 & $215.33 \pm 11.59^{\mathrm{b}}$ & $30.00 \pm 1.43^{\mathrm{d}}$ & $142.68 \pm 27.21^{\mathrm{ab}}$ & $36.14 \pm 1.55^{\mathrm{bc}}$ \\
\hline S17 & $677.00 \pm 37.32^{\mathrm{k}}$ & $25.00 \pm 0.71^{\mathrm{c}}$ & $159.32 \pm 15.29^{\mathrm{abc}}$ & $42.35 \pm 0.77^{\mathrm{cd}}$ \\
\hline S18 & $442.67 \pm 16.01^{\mathrm{fg}}$ & $25.00 \pm 0.71^{\mathrm{c}}$ & $155.30 \pm 2.17^{\mathrm{abc}}$ & $47.62 \pm 4.45$ de \\
\hline S19 & $567.33 \pm 39.11^{\mathrm{i}}$ & $20.00 \pm 1.43^{\mathrm{b}}$ & $277.44 \pm 8.65^{\text {ef }}$ & $60.80 \pm 0.14^{\mathrm{gh}}$ \\
\hline S20 & $602.33 \pm 33.86^{j}$ & $63.57 \pm 0.71^{j}$ & $266.08 \pm 230.565^{\text {def }}$ & $66.60 \pm 0.37^{\mathrm{h}}$ \\
\hline S21 & $679.00 \pm 9.85^{\mathrm{k}}$ & $58.57 \pm 1.43^{\mathrm{i}}$ & $249.16 \pm 11.64^{\text {cdef }}$ & $66.63 \pm 1.96^{\mathrm{h}}$ \\
\hline
\end{tabular}




\section{Table 5}

Values of $R^{2}(\mathrm{p}<0.05)$ obtained for Gauss-Newton analysis, which best describes the inhibition of dehydrogenase, urease, acid phosphatase, and arylsulfatase of the agricultural soils in the vicinity of brick kiln cluster and $\mathrm{ED}_{50}\left(\mathrm{mg} \cdot \mathrm{kg}^{-1}\right)$ expressed by total ecological toxicity coefficient, $P E R$

\begin{tabular}{llll}
\hline Soil Enzymes & Model & $\mathrm{ED}_{50}$ & $\mathrm{R}_{\mathbf{c}}$ \\
\hline Dehydrogenase & 1 & 299.75 & 0.69 \\
Urease & 2 & $\mathbf{6 3 3 . 2 8}$ & $\mathbf{0 . 7 2}$ \\
& 3 & 421.69 & 0.58 \\
& 1 & 32.21 & 0.35 \\
& 2 & $\mathbf{4 3 . 8 5}$ & $\mathbf{0 . 3 6}$ \\
Acid phosphatase & 1 & 19.94 & 0.31 \\
& 3 & 306.39 & 0.26 \\
Arylsulfatase & 2 & $\mathbf{5 0 7 . 8 1}$ & $\mathbf{0 . 3 0}$ \\
& 3 & 376.44 & 0.30 \\
& 1 & 124.85 & 0.38 \\
& 2 & $\mathbf{1 0 4 . 6 9}$ & $\mathbf{0 . 4 0}$ \\
& 3 & 93.15 & 0.36 \\
\hline
\end{tabular}

lease of enzymes, or a combination of both (Gao et al., 2010). Soil enzymes can be physically and chemically blocked by active organic and inorganic ligands (Renella et al., 2003). The $\mathrm{ED}_{50}$ values for dehydrogenase, urease, acid phosphatase and arylsulfatase activity were predicted with Model 2 . The dehydrogenase was most sensitive to metal addition and easily lost activity under low heavy metal concentration, urease and arylsulfatase activity were also sensitive to the combined heavy metal effect. The effect of heavy metal on acid phosphatase was found to be lower than the other enzymes as phosphatase activity was high heavy metal rate responsive to inhibit it. A significant relationship between soil enzymes and PER as fitted by Model 2, also indicates an adaptation of soil microorganisms in our study area. Sensitivity to metal toxicity varies for soil microorganisms. Sensitive populations decrease and remunerate with the increase of metal-tolerant strains in heavy metal stressed soil system (El Baz et al., 2015). The results of many experimental studies suggest that inhibition of soil enzymes due to heavy metal contamination can be reduced over time, and some microorganisms could be adapted to long term polluted environments and thereby help enzymatic activity to recover (Fazekašová and Fazekaš, 2020). The microorganism in our study site might be adapted to the high heavy metal concentration. Brick production activities are a long time regular practice in this zone. Cd concentration was found to be a very high toxic level in some highly contaminated soils enough to suppress complete microbial activity, but due to their adaption capacity, they survived with limited enzyme activity.

\subsection{Effects of soil properties and heavy metal contamination on size and activity of microbial biomass and enzyme activity}

Soil microorganisms are exposed to heavy metals via the soil solution with the ultimate impact on soil microbial biomass and soil enzyme activity. The concentration of heavy metals in soil solution depends upon soil processes mediated by $\mathrm{OM}, \mathrm{pH}$ and nutrient availability. Therefore, the type of soils plays a major role in the toxic effect of heavy metals on soil microorganisms. Some significant relationships between soil OM, MBC and
MA were found in the studied soils (Table 3) $(\mathrm{p}<0.001)$, which are involved in soil metabolic processes. Microbial population and activity and enzyme activities were correlated positively with soil $\mathrm{pH}$ (Table 3). Total nitrogen and AvP had a positive correlation with the number of culturable bacteria and fungi and SIR. Similar results have been obtained by Taylor et al., (2002). Soil pH can affect the adsorption/desorption of soil ions and soil nutrient transformation (Li et al., 2018). Chen et al., (2014) and Xian et al., (2015) showed the positive relationship between OM and dehydrogenase and arylsulfatase enzyme activity.

All the four enzymes were positively correlated $(p<0.05)$ with bacterial and fungal populations, SIR, MA, MBC (Fig. 2b). Dehydrogenase activity was significantly high in reference soil, where the soil microbiota was also metabolically more active than in contaminated agricultural soils (Table 2, 4). Since dehydrogenase is an intracellular enzyme involved in microbial metabolism, its lower activity in agricultural soil may be related to the smaller MBC content, but also a larger heavy metal concentration in agricultural than in reference soils. Furthermore, the dehydrogenase activity was significantly correlated with soil microbial biomass $C(r=0.61, p<0.05)$. The decrease of soil MBC and inhibition of dehydrogenase activity have been reported also in polluted areas near an aluminium smelter (Tscherko and Kandeler, 1997) These results suggest that MBC and dehydrogenase can be useful measures of the level of heavy metal contamination in a soil sample. Arylsulfatase, urease and acid phosphatase activity also showed a positive correlation with MBC ( $\mathrm{p}<0.05)$, MA and $q \mathrm{CO}_{2}(\mathrm{p}<0.05)$.

The results of this study found suppression of all the soil microbial properties and enzyme activities, which indicated the disruption of soil function by the $\mathrm{Cd}$ and $\mathrm{Pb}$ contamination in the vicinity of brick kiln cluster sites. The $q \mathrm{CO}_{2}$, which expresses the stress situation on soil microorganisms, with increasing $P E R$ was fitted by the exponential curve (Fig. 4). Regression analysis produced significant relationships between $P E R$ versus all the microbial properties and enzyme activities (Table 3). The microbial population as reduced by heavy metals which in turn showed a decrease in the activities of soil enzymes. Consequently, the decomposition rate of carbon, nitrogen, phosphorus and sulfur in soils would be blocked. Different enzymes have differ- 
Fig. 4. Relationship of $q \mathrm{CO}_{2}$ (metabolic quotient) with $P E R$ (comprehensive potential ecological index) in different agricultural soils besides brick kiln cluster, Hathazari, Chattogram. Regression equation, line of the best fit and $\mathrm{R}^{2}$ is shown. Filled circles representing the average $q \mathrm{CO}_{2}$ values and open circles representing the replications

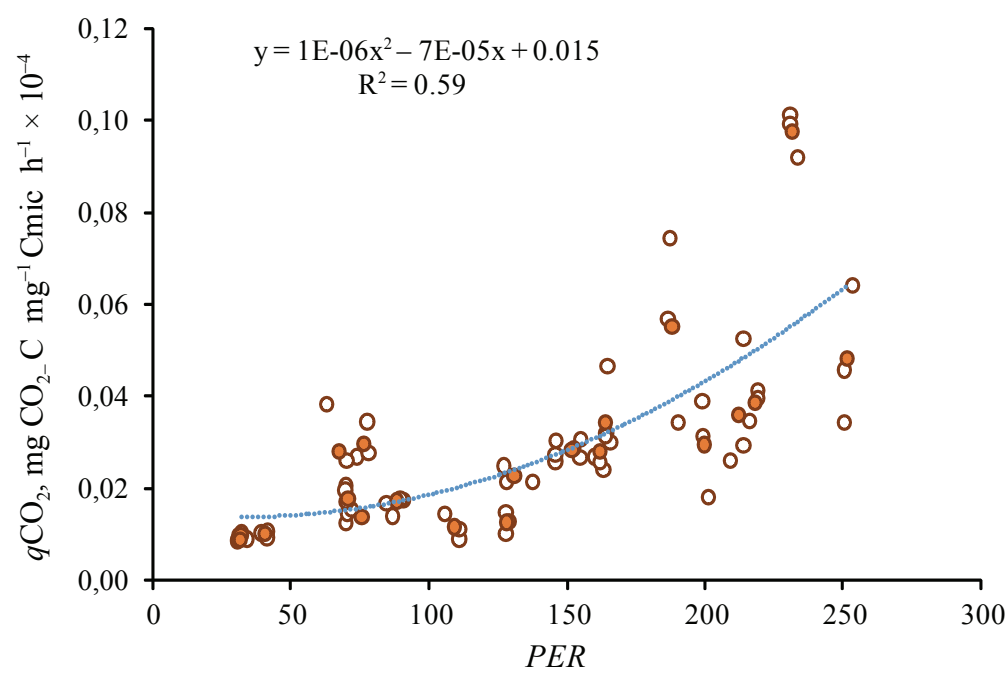

acterized by similar responses of soil microorganisms and their enzyme activity to heavy metal concentration and respective heavy metal indices along with soil physicochemical properties were performed (Fig. 5). The dendrogram revealed two main clusters of similarities with heavy metal contaminated soils. A cluster that contained S19, S20 and S21 along with S8 was significantly different from the other agricultural soils. The sites that are clustered together with the reference sites, we can tell that the environmental situation in these soils with a combination of $\mathrm{Cd}$ and $\mathrm{Pb}$ concentration with physicochemical characteristics of the soils, were not under any stressed condition.

Principal component analysis has commonly been used for investigating metal sources, anthropogenic activities, or soil parent materials (Kormoker et al., 2019). The depositions of atmospheric particulates released by brick kiln clusters were believed to contribute to $\mathrm{Cd}$ and $\mathrm{Pb}$ in investigated agricultural soils. A PCA was performed on a correlation matrix of the data obtained on soil microbial and enzymatic activities affected by soil physicochemical properties and soil $\mathrm{Cd}$ and $\mathrm{Pb}$ content (Fig. 6). The PCA revealed a strong relationship between enzymatic activities and soil microbial properties, and they varied together in the same trend upon toxic impact from heavy metals. The PCA analysis showed that microbial biomass and activities and all the enzyme activities were highly associated with soil $\mathrm{pH}$, $\mathrm{OM}$, and TN. Cd and $\mathrm{Pb}$ were significantly and positively associated with the heavy metal indices and $q \mathrm{CO}_{2}$. Dehydrogenase, acid phosphatase and arylsulfatase responded similarly to soil contamination with heavy metals, which is demonstrated by the proximity of vectors representing the analyzed enzymes. Urease and MA were also sensitive to heavy metals, but its response to heavy metals was somewhat different. This is illustrated by the position of the MA and urease vector relative to the soil heavy metal indices (PER). Distribution of sampling area in the PCA plot manifests the difference between the sampling sites concerning pollution levels and the impact on soil microbial biomass and enzyme activity. Gao et al., (2010) showed that absolute enzymatic activities varied under different land uses depending on the types of land use or management and the type of enzyme. 


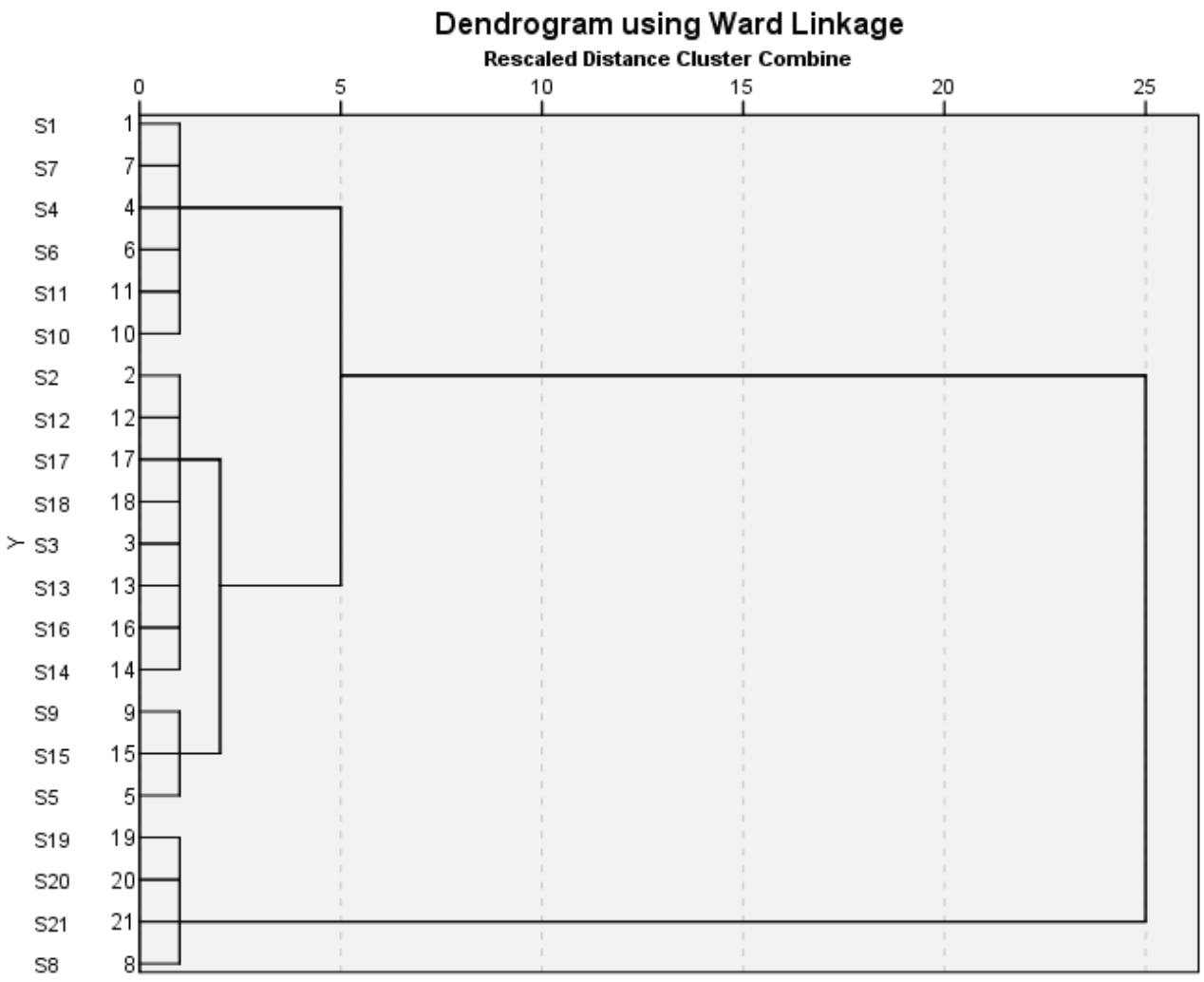

Fig. 5. Dendrogram of the hierarchical cluster analysis of $\mathrm{Cd}$ and $\mathrm{Pb}$ concentration in sampling sites with their impact on soil microbiological properties

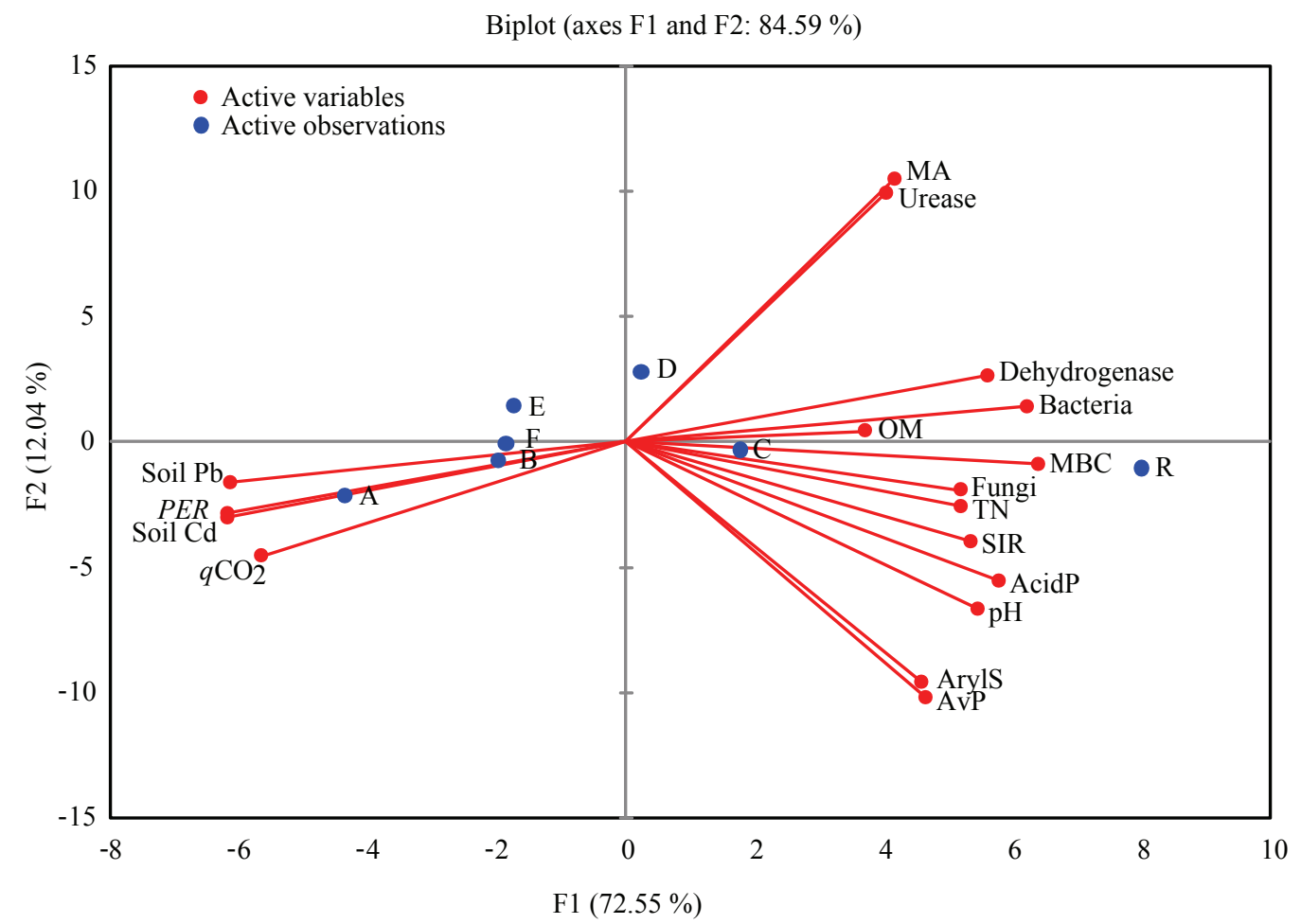

Fig. 6. PCA plot showing the similarity of agricultural soils around brick kiln cluster considering $\mathrm{Cd}$ and $\mathrm{Pb}$ concentration in sampling sites with their impact on soil microbiological properties 


\section{Conclusions}

The brick kiln industry has paramount importance in Bangladesh for modern establishments due to rapid urbanization and residential construction. The present study provided a comprehensive insight into the responses of soil microbial biomass and soil enzyme activities in agricultural soils related to brick kiln operation. This study showed that:

- Agricultural soil quality was low in the vicinity of brick kiln cluster than the reference sites concerning for soil OM and essential nutrients concentration

- $\quad$ The study area was contaminated with $\mathrm{Cd}$ and $\mathrm{Pb}$ (up to 1.07 $\mathrm{mg} \cdot \mathrm{kg}^{-1}$ soil and $52.07 \mathrm{mg} \cdot \mathrm{kg}^{-1}$ soil respectively) as compared to their background levels

- The heavy metal concentrations varied at the different agricultural sites but display a similar variation pattern

- $\quad \mathrm{Pb}$ concentration was found within the acceptable limit in soils when compared to the Chinese environmental quality standards for soil. On the other hand, Cd concentration was very high in the sampling areas.

- The $P E R$ which shows the extent of contamination by the heavy metals indicated moderate to a considerable level of contamination in the agricultural soils around the brick kiln cluster

- The intensive uncontrolled operation of brick kiln in the study area is a potential source of pollution in terms of heavy metal contamination

- The number of bacteria and fungi, respective the intensity of enzymatic activities and the microbial biomass carbon decreased with increasing heavy metal concentrations

- $\quad$ Microbial indices ( $q \mathrm{MIC}$ and $q \mathrm{CO}_{2}$ ) suggests the heavy metal stress as well as some microbial adaptation in the study area

- Cd was the most effective inhibitor on the dehydrogenase, arylsulfatase and acid phosphatase enzymes in this study

- $\quad$ The most sensitive to pollution was found to be with soil bacteria, MBC and dehydrogenase activities

\section{Acknowledgments}

This work was financially supported by the University Grants Commission, Bangladesh. The authors thank Mr. Tazul Islam for technical assistance.

\section{References}

Abdu, N., Abdullahi, A.A., Abdulkadir, A., 2017. Heavy metals and soil microbes. Environmental Chemistry Letters 15, 65-84. https://doi. org/10.1007/s10311-016-0587-x

Ahmed, M., Matsumoto, M., Kurosawa, K., 2018. Heavy metal contamination of irrigation water, soil, and vegetables in a multi-industry district of Bangladesh. International Journal of Environmental Research 12(4), 531-542. https://doi.org/10.3390/w11030583

Aktaruzzaman, M., Fakhruddin, A.N., Chowdhury, M.A., Fardous, Z., Alam, M.K., 2013. Accumulation of heavy metals in soil and their transfer to leafy vegetables in the region of Dhaka Aricha Highway, Savar, Bangladesh. Pakistan Journal of Biological Sciences 16(7), 332-338. https://doi.org/10.3923/pjbs.2013.332.338
Alam, R., Ahmed, Z., Howladar, M.F., 2020. Evaluation of heavy metal contamination in water, soil and plant around the open landfill site Mogla Bazar in Sylhet, Bangladesh. Groundwater for Sustainable Development 10. https://doi.org/10.1016/j.gsd.2019.100311

Alef, K., 1995. Soil respiration. [In:] Alef, K., Nannipieri, P. (Eds.), Methods in soil microbiology and biochemistry. Academic Press Inc., San Diego, 214-215.

Ali, H., Khan, E., Ilahi, I., 2019. Environmental chemistry and ecotoxicology of hazardous heavy metals: environmental persistence, toxicity, and bioaccumulation. Journal of Chemistry 14. https://doi. org/10.1155/2019/6730305

Anderson, T.H., Domsch, K.H., 1989. Ratios of microbial biomass carbon to total organic carbon in arable soils. Soil Biology and Biochemistry 21(4) 471-479. https://doi.org/10.1016/0038-0717(89)90117-X

Anderson, T.H., Domsch, K.H., 1990. Application of eco-physiological quotients ( $\mathrm{qCO}_{2}$ and $\mathrm{qD}$ ) on microbial biomasses from soils of different cropping histories. Soil Biology and Biochemistry 22(2), 251-255. https://doi.org/10.1016/0038-0717(90)90094-G

Anderson, J.M., Ingram J.S.I., 1993. A handbook of methods. CAB International, Wallingford, Oxfordshire.

BARC, 2012. Bangladesh Agricultural Research Council (BARC), Farmgate, Dhaka-1215.

Bisht, G., Neupane, S., 2015. Impact of brick Kilns' emission on soil quality of agriculture fields in the vicinity of selected Bhaktapur Area of Nepal. Applied and Environmental Soil Science 2015 8. https://doi. org/10.1155/2015/409401

Biswas, D., Gurley, E.S., Rutherford, S., Luby, S.P., 2018. The drivers and impacts of selling soil for brick making in Bangladesh. Environmental Management 62(4), 792-802. https://doi.org/10.1007/s00267-0181072-z

Brookes, P.C., 1995. The use of microbial parameters in monitoring soil pollution by heavy metals. Biology and Fertility of Soils 19(4), 269279. https://doi.org/10.1007/BF00336094

Casida. L.E., 1977. Microbial metabolic activity in soil as measured by dehydrogenase determinations. Applied and Environmental Microbiology 34(6) 630-636. https://doi.org/10.1128/aem.34.6.630636.1977

Chen, J., He, F., Zhang, X., Sun, X., Zheng, J., Zheng, J., 2014. Heavy metal pollution decreases microbial abundance, diversity and activity within particle-size fractions of a paddy soil. FEMS Microbiology Ecology 87(1),164-181. https://doi.org/10.1111/1574-6941.12212

Chen, S., Wang, M., Li, S., Zhao, Z.E.W., 2018. Overview on current criteria for heavy metals and its hint for the revision of soil environmental quality standards in China. Journal of Integrative Agriculture 17(4), 765-774. https://doi.org/10.1016/S2095-3119(17)61892-6

Chodak, M., Gołębiewski, M., Morawska-Płoskonka, J., Kuduk, K., Niklińska, M., 2013. Diversity of microorganisms from forest soils differently polluted with heavy metals. Applied Soil Ecology 64, 7-14. https://doi.org/10.1016/j.apsoil.2012.11.004

Chowdhury, N., Rasid, M.M., 2016. Heavy metal contamination of soil and vegetation in ambient locality of ship breaking yards in Chittagong. Bangladesh. Journal of Environmental Science, Toxicology and Food Technology 10(10), 20-27.

Day, P. R., 1965. Hydrometer method of particle size analysis. [In:] Black, C.A., (Ed.), Methods of soil analysis, American Society of Agronomy. Madison, Wisconsin Agronomy 9, 562-566.

Dick, W.A., 2011. Development of a soil enzyme reaction assay. Methods of soil enzymology 9, 71-84.

Eil, A., Li, J., Baral, P., Saikawa, E., 2020. Dirty Stacks, High Stakes: An Overview of Brick Sector in South Asia. The World Bank, 1818 H Street NW, Washington, DC 20433, USA.

Eivazi, F., Tabatabai, M.A., 1977. Phosphatases in soils. Soil Biology and Biochemistry 9(3), 167-172.

El Baz, S., Baz, M., Barakate, M., Hassani, L., El Gharmali, A., Imziln, B., 2015. Resistance to and accumulation of heavy metals by actinobac- 
teria isolated from abandoned mining areas. The Scientific World Journal (2015), 14. https//doi.org/10.1155/2015/761834

Fatima, I., Bhat, G.A., Kamili, A.N.G., 2011. Impact of brick kiln emissions on the ambient air quality and vegetation: A case study of district Budgam (Doctoral dissertation).

Fazekašová, D., Fazekaš, J., 2020. Quality and heavy metal pollution assessment of iron ore mines in Nizna Slana (Slovakia). Sustainability 12(6) 2549. https://doi.org/10.3390/su12062549

Gao, Y., Zhou, P., Mao, L., Zhi, Y., Shi, W., 2010. Assessment of effects of heavy metals combined pollution on soil enzyme activities and microbial community structure: modified ecological dose-response model and PCR-RAPD. Environmental Earth Sciences 60(3), 603-612. https://doi.org/10.1007/s12665-009-0200-8

Garcýa-Gil, J. C., Plaza, C., Soler-Rovira, P., Polo, A., 2000. Long-term effects of municipal solid waste compost application on soil enzyme activities and microbial biomass. Soil Biology and Biochemistry 32(13), 1907-1913. https://doi.org/10.1016/S0038-0717(00)00165-6

García Gil, J., Kobza, J., Soler Rovira, P., Javoreková, S., 2013. Soil microbial and enzyme activities response to pollution near an aluminium smelter. Clean-Soil, Air, Water 41 (5), 485-492. https://doi.org/10.1002/ clen.201200099

Guo, W., Liu, X., Liu, Z., Li, G., 2010. Pollution and potential ecological risk evaluation of heavy metals in the sediments around Dongjiang Harbor, Tianjin. Procedia Environmental Sciences 2, 729-736. https://doi. org/10.1016/j.proenv.2010.10.084

Haque, M.I., Nahar, K., Kabir, M.H., Salam, A., 2018. Particulate black carbon and gaseous emission from brick kilns in Greater Dhaka region, Bangladesh. Air Quality, Atmosphere \& Health 11(8), 925-935.

Hasan, A.B., Reza, A.S., Kabir, S., Siddique, M.A.B., Ahsan, M.A., Akbor, M.A., 2020. Accumulation and distribution of heavy metals in soil and food crops around the ship breaking area in southern Bangladesh and associated health risk assessment. SN Applied Sciences 2(2), 155. https://doi.org/10.1007/s42452-019-1933-y

Hazelton, P., Murphy, B., 2016. Interpreting soil test results: What do all the numbers mean? CSIRO Publishing.

Humberto, A., Paula, M., Butler, B., Jorge, P., Matus, F., Merino, C., Cornejo, P., Yakov, K., 2020. Meta-analysis of heavy metal effects on soil enzyme activities. Science of The Total Environment 139744. https://doi. org/10.1016/j.scitotenv.2020.139744

Imran, M.A., Baten, M.A., Nahar, B.S., Morshed, N., 2014. Carbon dioxide emission from brickfields around Bangladesh. International Journal of Agricultural Research, Innovation and Technology 4(2), 70-75.

Islam, M.S., Hoque, M.F., 2014. Concentrations of heavy metals in vegetables around the industrial area of Dhaka city, Bangladesh and health risk assessment. International Food Research Journal 21(6).

Islam, M.S., Al Mamun, S., Muliadi, M., Rana, S., Tusher, T. R., Roy, S., 2015. The impact of brick kiln operation to the degradation of topsoil quality of agricultural land. Agrivita 37(3), 204-209. https://doi. org/10.17503/agrivita.v37i3.596

Ismail, M., Muhammad, D., Khan, F.U., Munsif, F., Ahmad, T., Ali, S., Khalid, M., Haq, N., Ahmad, M., 2012. Effect of brick kilns emissions on heavy metal ( $\mathrm{Cd}$ and $\mathrm{Cr}$ ) content of contiguous soil and plants. Sarhad Journal of Agriculture 28(3), 403-409.

Jackson, M.L., 1973. Soil chemical analysis. Prentice Hall of India Ltd. New Delhi.

Johnson, L.F., Curl, E.A., 1972. Methods for research on the ecology of soil-borne plant pathogens. No. 04; QR111, J6. Minneapolis: Burgess.

Karaca A., Cetin S.C., Turgay O.C., Kizilkaya R., 2010. Soil Enzymes as indication of soil quality. [In:] Shukla, G., Varma, A. (Eds.), Soil enzymology. Soil Biology (22). Springer, Berlin, Heidelberg. https://doi. org/10.1007/978-3-642-14225-3_7

Khan, S., Cao, Q., Zheng, Y.M., Huang, Y.Z., Zhu, Y.G., 2008. Health risks of heavy metals in contaminated soils and food crops irrigated with wastewater in Beijing, China. Environmental Pollution 152(3), 686692. https://doi.org/10.1016/j.envpol.2007.06.056
Khan, M.H., Rahman, M.K., Rouf, A.J.M.A., Sattar, G.S., Akhtar, M.S., Oki, Y., Adachi, T., 2007. Effects of brick burning on microbial biomass and $\mathrm{C} / \mathrm{N}$ ratio in selected soil profiles in the eastern region of Bangladesh. Journal of Faculty of Environmental Science and Technology, Okayama University 12(1), 83-89. http://doi.org/10.18926/fest/11443

Kormoker, T., Proshad, R., Islam, S., Ahmed, S., Chandra, K., Uddin, M., Rahman, M., 2019. Toxic metals in agricultural soils near the industrial areas of Bangladesh: ecological and human health risk assessment. Toxin Reviews, 1-20. https://doi.org/10.1080/15569543.2019.1650777

Li, P., Lin, C., Cheng, H., Duan, X., Lei, K., 2015. Contamination and health risks of soil heavy metals around a lead/zinc smelter in southwestern China. Ecotoxicology and Environmental Safety 113, 391-399. https:// doi.org/10.1016/j.ecoenv.2014.12.025

Li, Q., Hu, Q., Zhang, C., Jin, Z., 2018. Effects of Pb, Cd, Zn, and Cu on soil enzyme activity and soil properties related to agricultural land-use practices in Karst area contaminated by $\mathrm{Pb}-\mathrm{Zn}$ tailings. Polish Journal of Environmental Studies 27(6), 2623-2632. https://doi.org/10.15244/ pjoes $/ 81213$

Liao, M., Xie, X. M., 2007. Effect of heavy metals on substrate utilization pattern, biomass, and activity of microbial communities in a reclaimed mining wasteland of red soil area. Ecotoxicology and Environmental safety 66(2), 217-223. https://doi.org/10.1016/j.ecoenv.2005.12.013

Mallick, S.R., Proshad, R., Islam, M.S., Sayeed, A., Uddin, M., Gao, J., Zhang, D., 2019. Heavy metals toxicity of surface soils near industrial vicinity: A study on soil contamination in Bangladesh. Archives of Agriculture and Environmental Science 4(4), 356-368. https://doi.org/10.268 32/24566632.2019.040401

Nelson, D.W., Sommers, L.E., 1982. Total carbon, organic carbon, and organic matter. [In:] Page A.L., Miller. R.H., Keeney, D.R. (Eds.) Methods of soil analysis. Part 2. Chemical and Microbiological Properties. Agronomy Monograph 9. ASA and SSSA, Madison, WI.

Orrońo, D.I., Lavado, R.S., 2009. Distribution of extractable heavy metals in different soil fractions. Chemical Speciation \& Bioavailability 21(4), 193-198. https://doi.org/10.3184/095422909X12473204137916

Pan, J., Yu, L., 2011. Effects of Cd or/and Pb on soil enzyme activities and microbial community structure. Ecological Engineering 37, 18891894. https://doi.org/10.1016/j.ecoleng.2011.07.002

Proshad, R., Islam, M.S., Kormoker, T., Bhuyan, M.S., Hanif, M.A., Hossain, N., 2019. Contamination of heavy metals in agricultural soils. Ecological and health risk assessment. SF Journal of Nano chemistry and Nanotechnology 2 (1), 1012.

Ravankhah, N., Mirzaei, R., Masoum, S., 2017. Determination of heavy metals in surface soils around the brick kilns in an arid region, Iran. Journal of Geochemical Exploration 176, 91-99. https://doi. org/10.1016/j.gexplo.2016.01.005

Renella, G., Ortigoza, AL. R., Landi, L., Nannipieri, P., 2003. Additive effects of copper and zinc on cadmium toxicity on phosphatase activities and ATP content of soil as estimated by the ecological dose $\left(\mathrm{ED}_{50}\right)$. Soil Biology and Biochemistry 35(9), 1203-1210. https://doi. org/10.1016/S0038-0717(03)00181-0

Rieuwerts, J.S., Thornton, I., Farago, M.E., Ashmore, M.R., 1998. Factors influencing metal bioavailability in soils: preliminary investigations for the development of a critical loads approach for metals. Chemical Speciation \& Bioavailability 10(2), 61-75.

Rodella, A.A., Saboya, L.V., 1999. Calibration for conductimetric determination of carbon dioxide. Soil Biology and Biochemistry 31(14), 2059-2060. https://doi.org/10.1016/s0038-0717(99)00046-2

Sarkar, D., Pal, M., Sarkar, A.K., Mishra, U., 2016. Evaluation of the properties of bituminous concrete prepared from brick-stone mix aggregate. Advances in Materials Science and Engineering, 7. https:// doi.org/10.1155/2016/2761038

Sharma, B., Sarkar, A., Singh, P., Singh, R.P., 2017. Agricultural utilization of biosolids: a review on potential effects on soil and plant grown. Waste Management 64, 117-132. https://doi.org/10.1016/ j.wasman.2017.03.002 
Sharma, N.K., 2000. Effect of air pollution emitted from brick kilns on growth performance and soil characteristics of some rabi and kharif crops. Pollution Research 19(4), 657-659.

Shukla, G., Varma, A., 2011. Soil enzymes. Springer, Berlin, Heidelberg. https://doi.org/10.1007/978-3-642-14225-3

Skinder, B.M., Sheikh, A.Q., Pandit, A.K., Ganai, B.A., 2014. Brick kiln emissions and its environmental impact: A review. Journal of Ecology and the Natural Environment 6(1), 1-11. https://doi.org/10.5897/ JENE2013.0423

Soil Resource Development Institute (SRDI), 2008. Land and soil resource utilization guide (Upazila Nirdeshika, in Bengali): 91(18), Khulna Barisal Chittagong Divisions.

Srivastava, V., Sarkar, A., Singh, S., Singh, P., de Araujo, A. S., Singh, R. P., 2017. Agro ecological responses of heavy metal pollution with special emphasis on soil health and plant performances. Frontiers in Environmental Science 5(64). https://doi.org/10.3389/fenvs.2017.00064

Tabatabai, M.A., Bremner, J.M., 1972. Assay of urease activity in soils. Soil Biology and Biochemistry 4(4), 479-487.

Tabatabai, M.A., Bremner, J.M., 1970. Arylsulfatase activity of soils. Soil Science Society of America Journal 34(2), 225-229.

Tang, J., Zhang, L., Zhang, J., Ren, L., Zhou, Y., Zheng, Y., Luo, L., Yang, Y., Huang, H., Chen, A., 2020. Physicochemical features, metal availability and enzyme activity in heavy metal-polluted soil remediated by biochar and compost. Science of the Total Environment 701,134751. https://doi.org/10.1016/j.scitotenv.2019.134751

Tasrina, R.C., Rowshon, A., Mustafizur, A.M.R., Rafiqul, I., Ali, M.P., 2015. Heavy metals contamination in vegetables and its growing soil. Journal of Environmental Analytical Chemistry 2(3). https://doi. org/10.41722380-2391.1000142

Taylor, J.P., Wilson, B., Mills, M.S., Burns, R.G., 2002. Comparison of microbial numbers and enzymatic activities in surface soils and subsoils using various techniques. Soil Biology and Biochemistry 34(3), 387-401. https://doi.org/10.1016/S0038-0717(01)00199-7

Tietjen, T., Wetzel, R.G., 2003. Extracellular enzyme-clay mineral complexes: Enzyme adsorption, alteration of enzyme activity, and protection from photodegradation. Aquatic Ecology 37(4), 331-339. https:// doi.org/10.1023/B:AECO.0000007044.52801.6b

Tscherko, D., Kandeler, E., 1997. Eco toxicological effects of fluorine deposits on microbial biomass and enzyme activity in grassland. European Journal of Soil Science 48(2), 329-335. https://doi.org/10.1111/ j.1365-2389.1997.tb00553.x

Tusher, T.R., Ashraf, Z., Akter, S., 2018. Health effects of brick kiln operations: A study on largest brick kiln cluster in Bangladesh. South East Asia Journal of Public Health. 8(1), 32-36. https://doi.org/10.3329/seajph.v8i1.42270

Ure, A.M., 1990. Methods of analysis of heavy metals in soils. [In:] Alloway, B.J. (Ed.) Heavy metals in soils. New York: John Wiley.

Wang, Y., Shi, J., Wang, Y., Lin, Q., Chen, X., Chen, Y., 2007. The influence of soil heavy metals pollution on soil microbial biomass, enzyme activity, and community composition near a copper smelter. Ecotoxicology and Environmental safety 67(1), 75-81. https://doi.org/10.1016/ j.ecoenv.2006.03.007
Wang, Y., Li, Q., Shi, J., Lin, Q., Chen, X., Wu, W., Wu, W., Chen, Y., 2008. Assessment of microbial activity and bacterial community composition in the rhizosphere of a copper accumulator and a non-accumulator. Soil Biology and Biochemistry 40(5), 1167-1177. https://doi. org/10.1016/j.soilbio.2007.12.010

website 1: http://en.banglapedia.org/index.php?title=Climate

website 2: https://www.nrcs.usda.gov/wps/portal/nrcs/detail/soils/survey/ ?cid=nrcs142p2_054167

West, A.W., Sparling, G.P., 1986. Modifications to the substrate-induced respiration method to permit measurement of microbial biomass in soils of differing water contents. Journal of Microbiological Methods 5(3-4), 177-189. https://doi.org/10.1016/0167-7012(86)90012-6

Wieczorek, J., Baran, A., Urbański, K., Mazurek, R., Klimowicz-Pawlas, A., 2018. Assessment of the pollution and ecological risk of lead and cadmium in soils. Environmental Geochemistry and Health 40(6), 2325-2342.

Wyszkowska, J., Kucharski, J., Borowik, A., Boros, E., 2008. Response of bacteria to soil contamination with heavy metals. Journal of Elementology 13(3), 443-453.

Wyszkowska, J., Karol, W., Kucharski, J., 2016. Resistance of arylsulfatase to contamination of soil by heavy metals. Polish Journal of Environmental Studies 25(1), 365-375. https://doi.org/10.15244/pjoes/60417

Xian, Y., Wang, M., Chen, W., 2015. Quantitative assessment on soil enzyme activities of heavy metal contaminated soils with various soil properties. Chemosphere 139, 604-608. https://doi.org/10.1016/ j.chemosphere. 2014.12.060.

Yang, Y., Campbell, C.D., Clark, L., Cameron, C.M., Paterson. E., 2006. Microbial indicators of heavy metal contamination in urban and rural soils. Chemosphere 63(11), 1942-1952. https://doi.org/10.1016/j.chemosphere.2005.10.009

Yuan, L., Zhi, W., Liu, Y., Karyala, S., Vikesland, P.J., Chen, X., Zhang, H., 2015. Lead toxicity to the performance, viability, and community composition of activated sludge microorganisms. Environmental Science and Technology 49, 824-830. https://doi.org/10.1021/ es504207c

Zakir, H.M., Sultana, N., Akter, M., 2014. Heavy metal contamination in roadside soils and grasses: A case study from Dhaka city, Bangladesh. Journal of Chemical, Biological and Physical Sciences 4(2), 1661-1673.

Zhang, Y.L., Dai, J.L., Wang, R.Q., Zhang, J., 2008. Effects of long-term sewage irrigation on agricultural soil microbial structural and functional characterizations in Shandong, China. European Journal of Soil Biology 44(1), 84-91. https://doi.org/10.1016/j.ejsobi.2007.10.003

Zhao, X., Sun, Y., Huang, J, Wang, H., Tang, D., 2020. Effects of soil heavy metal pollution on microbial activities and community diversity in different land use types in mining areas. Environmental Science and Pollution Research 27, 20215-20226. https://doi.org/10.1007/s11356020-08538-1

Zhuang, P., McBride, M.B., Xia, H., Li, N., Li, Z., 2009. Health risk from heavy metals via consumption of food crops in the vicinity of Dabaoshan mine, South China. Science of the Total Environment 407(5), 1551-1561. https://doi.org/10.1016/j.scitotenv.2008.10.061 